NORTH CAROLINA BANKING INSTITUTE

Volume 23 | Issue 1

Article 8

$3-1-2019$

\title{
Bitcoin Futures: From Self-Certification to Systemic Risk
}

Lee Reiners

Follow this and additional works at: https://scholarship.law.unc.edu/ncbi

Part of the Banking and Finance Law Commons

\section{Recommended Citation}

Lee Reiners, Bitcoin Futures: From Self-Certification to Systemic Risk, 23 N.C. BANKING INST. 61 (2019).

Available at: https://scholarship.law.unc.edu/ncbi/vol23/iss1/8

This Article is brought to you for free and open access by Carolina Law Scholarship Repository. It has been accepted for inclusion in North Carolina Banking Institute by an authorized editor of Carolina Law Scholarship Repository. For more information, please contact law_repository@unc.edu. 


\title{
BITCOIN FUtURES: FROM SELF-CERTIFICATION TO SYSTEMIC RISK
}

\author{
LEE REINERS*
}

\section{INTRODUCTION}

December 2017 marked a milestone in the short history of virtual currency. On Friday, December 1, 2017, the Chicago Mercantile Exchange Inc. ("CME") and the CBOE Futures Exchange ("CFE") self-certified new contracts for cash-settled bitcoin futures products. ${ }^{1}$ The selfcertification process allows designated contract markets ("DCMs") to list new derivative products one day after submitting in writing to the Commodity Futures Trading Commission ("CFTC") that the product complies with the Commodity Exchange Act ("CEA") and CFTC regulations. ${ }^{2}$ Bitcoin first came under the CFTC's remit in 2015, when the agency determined, in an order against Coinflip, Inc., that bitcoin — and by extension all other virtual currencies - met the definition of a commodity under the CEA. ${ }^{3}$ The CFTC has jurisdiction over commodity derivatives, but they do not oversee commodity "spot" or cash markets, except in

*Lecturing Fellow and Executive Director of the Global Financial Markets Center at Duke University School of Law. The author would like to thank Ryan Clements for helpful comments and edits.

1. Also, on December 1, 2017, the Cantor Exchange self-certified a new contract for bitcoin binary options. This Article focuses exclusively on bitcoin futures contracts because they are more liquid, and more likely to be manipulated than binary options. See U.S. Commodity Futures Trading Comm'n, CFTC Backgrounder on Self-Certified CONTRACTS FOR BITCOIN PRODUCTS (2017), https://www.cftc.gov/sites/default/files/idc/groups/public/@newsroom/documents/file/bitcoin_factsheet120117.pdf.

2. 17 C.F.R. $\S 40.2$ (2018).

3. In re Coinflip, Inc., CFTC No. 15-29 (Sept. 17, 2015), https://www.cftc.gov/sites/default/files/idc/groups/public/@lrenforcementactions/documents/legalpleading/enfcoinfliprorder09172015.pdf. 
instances of fraud or manipulation. ${ }^{4}$ As a result, no federal agency supervises virtual currency exchanges in the U.S. ${ }^{5}$

Prior to December 2017, there were limited options for U.S. investors that wanted access to bitcoin derivatives. In 2014, TeraExchange, LLC, a Swap Execution Facility ("SEF") registered with the CFTC, began listing bitcoin swaps for trading by "eligible contract participants." 6 Also in 2014, North American Derivatives Exchange Inc., a DCM, listed binary bitcoin options that were available to retail investors. ${ }^{7}$ Then in July of 2017, the CFTC approved LedgerX's application to become a SEF and a Derivatives Clearing Organization ("DCO"), thereby allowing LedgerX to offer physically-settled bitcoin put and call options and dayahead swaps to eligible contract participants. ${ }^{8}$

Early bitcoin derivatives had limited appeal because they were illiquid, due in part to their bespoke features and the fact that they traded on venues that were relatively new and unknown, resulting in low trading volumes. In addition, access to early bitcoin derivatives was primarily limited to wealthy investors. When bitcoin futures launched, every investor now had access to a liquid product that traded on two of the world's largest futures exchanges ${ }^{9}$ and that could be bought and sold through online retail brokers like E-Trade and TD Ameritrade. ${ }^{10}$

The latent demand for bitcoin futures revealed itself when CFE launched their contract on December 10, 2017. CFE was forced to halt

4. CFTC jurisdiction is also implicated when a commodity is offered for trading on a margined, leveraged, or financed basis. See LABCFTC, A CFTC PRIMER ON VIRTUAL CURRENCIES 11 (Oct. 17, 2017), https://www.cftc.gov/sites/default/files/idc/groups/public/documents/file/labcftc_primercurrencies100417.pdf.

5. The U.S. Department of the Treasury's Financial Crimes Enforcement Network ("FinCEN") does consider "administrators" and "exchangers" of convertible virtual currencies to be money services businesses subject to regulations implementing the Bank Secrecy Act. See Fin. Crimes Enforcement Network, Application of FinCEN's Regulations to Persons Administering, Exchanging, or Using Virtual Currencies (Mar. 18, 2013), https://www.fincen.gov/resources/statutes-regulations/guidance/application-fincens-regulations-persons-administering.

6. An "eligible contract participant" is a type of sophisticated trader, which includes various financial institutions and persons, with assets above specified statutory minimums. See 7 U.S.C $\S 1 \mathrm{a}(18)(\mathrm{A})(\mathrm{iv})$ (2012).

7. See LABCFTC, supra note 4, at 12.

8. See LABCFTC, supra note 4, at 12.

9. CME is the world's largest futures exchange by volume and CBOE Holdings is the fourth largest. See Largest Derivatives Exchanges Worldwide in 2017, by Number of Contracts Traded (in Millions), STATISTA, https:/www.statista.com/statistics/272832/largest-international-futures-exchanges-by-number-of-contracts-traded/ (last visited Nov. 2, 2018).

10. On their website, Cboe provides a list of brokers that offer trading in their futures contract. See CbOe, XBT-Cboe Bitcoin Futures, http://cfe.cboe.com/cfe-products/xbtcboe-bitcoin-futures (last visited Jan. 22, 2019). 
trading two and a half hours after trading opened, when the futures price rose by $10 \%$ and tripped the exchange's automatic circuit breaker. ${ }^{11}$ The first few days of futures trading saw the one-month contract trading for approximately $\$ 1,000$ more than bitcoin's spot price. ${ }^{12}$ This meant a riskfree profit could be had by borrowing to buy one bitcoin while simultaneously selling a future; then in one month, you would sell the bitcoin and deliver the cash to settle the future. ${ }^{13}$ Whenever the futures price trades above the spot price for any asset, it typically indicates that there are costs associated with holding the underlying asset, but bitcoin is a digital asset that is theoretically costless to hold. ${ }^{14}$

The introduction of CFE's contract coincided with the largest one-week price increase (in dollar value) in bitcoin's history, with the price rising from $\$ 15,168$ on December 10, 2017, to an all-time high of $\$ 20,089$ on December $17,2017^{15}$ - the day CME launched their futures contract. Bitcoin euphoria came to an abrupt end post-CME contract launch, and by year-end 2017 , bitcoin was trading at $\$ 14,156 .{ }^{16}$ Researchers at the Federal Reserve Bank of San Francisco have attributed this rapid decline in bitcoin's price to the presence of speculators utilizing

11. Rob Urban et al., Bitcoin Futures Deliver Wild Ride as Debut Brings Rally, Halts, BLOOMBERG (Dec. 11, 2017), https://www.bloomberg.com/news/articles/2017-1210/bitcoin-futures-trading-opens-bringing-crypto-to-wall-street.

12. See, e.g., Matt Levine, Bitcoin Arbitrage and Tax Math, BloomBerg (Dec. 12, 2017), https:/www.bloomberg.com/opinion/articles/2017-12-12/bitcoin-arbitrage-and-tax-math (discussing the arbitrage opportunities in the early days of bitcoin futures trading).

13. Your risk-free profit would be the price at which you sold the future minus the price you paid for the bitcoin plus any borrowing costs. See, e.g., Matt Levine, Bitcoin Futures and Banky Thoughts, BLOOMBERG (Dec. 11, 2017), https://www.bloomberg.com/opinion/articles/2017-12-11/bitcoin-futures-and-banky-thoughts (discussing how you would profit off the difference between bitcoin's spot price and the future's price).

14. For instance, oil futures often trade above the spot price for oil because it is costly to store oil. Because bitcoin is a digital asset that is theoretically costless to hold, the arbitrage opportunity must be due to other factors. The primary explanation is that investors want exposure to bitcoin without having to acquire it and they are willing to pay a premium to own the futures contract (another contributing factor is that there are significant frictions in the market which prevent arbitrageurs from capturing the risk-free profit). Running a node on the bitcoin network requires a fairly high level of technological sophistication and the ability to keep your private key - a string of alphanumeric characters unique to each user-secure. Lacking such sophistication, many bitcoin holders chose to store their bitcoin in digital wallets or online exchanges, which are frequently hacked, resulting in the irrecoverable theft of customer bitcoins. See Levine, supra note 13.

15. All bitcoin price data in this Article comes from CoinMarkepCap. COINMARKETCAP, https://coinmarketcap.com/currencies/bitcoin/historical-data/ (last visited Jan. 22, 2019).

16. Bitcoin would continue to decline throughout 2018, and ended the year trading at $\$ 3,742 . I d$. 
bitcoin futures to bet against bitcoin. ${ }^{17}$ Prior to bitcoin futures, these pessimists "had no mechanism available to put money behind their belief that the bitcoin price would collapse." 18 Others have pushed back on the idea that bitcoin futures materially impact the price of bitcoin, ${ }^{19}$ noting the limited open interest in the contracts and the fact that the contracts are cash settled, ${ }^{20}$ meaning no actual bitcoins are exchanged.

While it is difficult to know the precise impact cash-settled futures have on bitcoin's price, it is clear from early experience that bitcoin futures serve primarily as a means to speculate on the price of bitcoin and not as a true hedging instrument. This outcome was widely anticipated at the time bitcoin futures were launched, and led many market participants and observers to question why the CFTC allowed bitcoin futures to come to market. ${ }^{21}$ The CFTC responded by noting that Congress established the self-certification process and they had limited grounds for halting a self-certification - none of which were met in the case of bitcoin futures. $^{22}$

This Article challenges the CFTC's assertion that CME and CFE met all the requirements to self-certify bitcoin futures contracts. CFTC regulation requires that any new contract not be readily susceptible to manipulation, but a careful review of the record indicates that bitcoin futures are susceptible to manipulation because the bitcoin spot market can

17. Galina Hale et al., How Futures Trading Changed Bitcoin Prices, Fed. REs. BanK of SAN FrANCISCO ECON. LETTER (May 7, 2018), https://www.frbsf.org/economic-research/publications/economic-letter/2018/may/how-futures-trading-changed-bitcoin-prices/.

18. Id.

19. Chris Concannon, president and chief operating officer at Cboe Global Markets, Inc. said: "While we are excited about our recently launched Bitcoin futures, the notion that they have materially affected the bitcoin price overstates their influence and ignores other critical facts. Our strict position limits and the limited open interest in our May and June settlements, suggest that the fall of Bitcoin can be more easily explained by other factors such as the recent regulatory scrutiny around the globe, steps by government tax collectors, the rise of other cryptocurrencies, and declining media interest in the asset." Oscar Williams-Grut, Bitcoin Futures Could be Hurting Bitcoin's Price, Bus. InSIDER Austl. (June 18, 2018), https://www.businessinsider.com.au/bitcoin-price-could-be-hit-by-bitcoin-futures-contractssays-tom-lee-2018-6.

20. See, e.g., Zhuoqi Gao, Using CBOE Bitcoin Futures to Predict Underlying Bitcoin Price Direction, SEeKING AlPHA (Mar. 25, 2018), https://seekingalpha.com/article/4158704using-cboe-bitcoin-futures-predict-underlying-bitcoin-price-direction.

21. See, e.g., Gabriel T. Rubin, Rise of Bitcoin Futures Prompts Regulator to Revisit Hands-Off Approach, WALl ST. J. (Jan. 31, 2018), https://www.wsj.com/articles/rise-ofbitcoin-futures-prompts-regulator-to-revisit-hands-off-approach-1517394600.

22. COMmOdity Futures Trading COMM'N, CFTC BACKGROUNDER ON OVERSIGHT OF AND Approach to Virtual Currency Futures Markets 2 (Jan. 4, 2018), https://www.cftc.gov/sites/default/files/ide/groups/public/\%40customerprotection/documents/file/backgrounder_virtualcurrency01.pdf. 
be manipulated. In reviewing the contracts leading up to their self-certification, the CFTC ignored underlying dynamics in the bitcoin spot market and chose to exclusively focus on the ability of the contracts themselves to be manipulated. This Article casts doubt on the notion that a futures contract can be resistant to manipulation when the asset underlying the contract is readily manipulated.

In asserting this contention, the Article will proceed as follows. First, in Part II, it traces the evolution of the new product approval process for derivatives. ${ }^{23}$ It describes how common law considered derivatives to be speculation (and akin to gambling), and therefore prohibited legal enforceability of derivatives contracts. This pushed derivatives speculation onto private exchanges that enforced the contracts through a system of rules and requirements on exchange members. Private exchanges were essentially free to determine their own rules until 1974, when amendments to the CEA required the CFTC to approve all new exchange rules pertaining to the "terms and conditions in contracts of sale." 24 This affirmative process lasted until 2000, when the Commodity Futures Modernization Act ("CFMA") effectively deregulated the derivatives market and instituted the self-certification regime, which gave exchanges much greater freedom to list new derivatives products. Part II concludes by examining how the self-certification process was used to list bitcoin futures and the CFTC's review of these products leading up to their selfcertification.

Part III assesses the ability of bitcoin futures to comply with the CFTC's Core Principle 3: " $[\mathrm{t}]$ he board of trade shall list on the contract market only contracts that are not readily susceptible to manipulation." 26 Because bitcoin futures are cash-settled, they can be manipulated if the reference rate used to price the contracts at settlement can be manipulated. The price of bitcoin varies depending on the exchange it trades on, therefore, $\mathrm{CME}$ and $\mathrm{CFE}$ had to carefully construct a reference rate for their futures contracts that could not be manipulated. CFE's futures contract relies on the Gemini Exchange's daily bitcoin auction to determine the contract's settlement value. However, Gemini lacks sufficient trading volume to facilitate price discovery and their daily auction often fails to clear a single bitcoin. CME calculates a bitcoin reference rate based upon

23. See infra Part II.

24. Philip McBide Johnson et Al., Derivatives Regulation 497 (2018).

25. See infra Part III.

26. 17 C.F.R. $\S 38.200$. 
data provided by four "Constituent Exchanges." In their self-certification submission, CME noted two additional exchanges that are temporarily suspended from submitting pricing data-OkCoin and Bitfinex. The mention of these two exchanges should have been a red flag for the CFTC, as they both have a troubled history, especially Bitfinex, which has been accused of propping up the entire bitcoin spot market throughout much of 2017. ${ }^{27}$ Not only did the CFTC fail to find fault with either reference rate, they also chose to ignore clear evidence of fraud and manipulation in the bitcoin spot market. The Securities and Exchange Commission ("SEC") took a different approach when reviewing a proposal for a bitcoin exchange-traded product and concluded that manipulation in the bitcoin spot market precluded any kind of exchange-traded product tied to bitcoin. ${ }^{28}$

Part IV assesses the impact of bitcoin futures on systemic risk. While the virtual currency market at present is not large enough to threaten financial stability, the introduction of bitcoin futures creates new interconnections within the financial system that could one day propagate systemic risk should the market continue to grow. Bitcoin futures pierced the previous barrier that had largely separated the virtual currency market from the regulated financial system. Now, large Wall Street firms offer their clients access to bitcoin futures, which trade on regulated exchanges and are cleared on systemically important clearinghouses. In addition, these parties may not fully understand the risks they are taking on due to bitcoin's novelty and complexity. The financial crisis of 2008 serves as a stark reminder of what can happen when seemingly sophisticated financial institutions trade complex derivatives.

Part V concludes by assessing the role of bitcoin futures in integrating the virtual currency market with the broader financial system and highlights several proposals for amending the new product approval process.

27. See, e.g., John M. Griffin \& Amin Shams, Is Bitcoin Really Un-Tethered? (June 13, 2018), https://papers.ssrn.com/sol3/papers.cfm?abstract_id=3195066 (discussing Bitfinex's use of Tether to support the price of bitcoin).

28. See Order Disapproving a Proposed Rule Change to BZX Rule 14.11(e)(4), Exchange Act Release No. 34-80206, 116 S.E.C. Dockets 2746 (Mar. 10, 2017), https://www.sec.gov/rules/sro/batsbzx/2017/34-80206.pdf, at 2 [hereinafter SEC Disapproval Order]. 


\section{New Product ApProval Process}

\section{A. Historical Overview of U.S. Futures Regulation}

In 1974, Congress passed the Commodity Futures Trading Commission Act, which overhauled the Commodity Exchange Act and established the Commodity Futures Trading Commission, granting the CFTC exclusive jurisdiction over futures trading in all commodities. ${ }^{29}$ The CEA was designed to:

[d]eter and prevent price manipulation or any other disruptions to market integrity; to ensure the financial integrity of all transactions subject to this chapter and the avoidance of systemic risk; to protect all market participants from fraudulent or other abusive sales practices and misuses of customer assets; and to promote responsible innovation and fair competition among boards of trade, other markets and market participants. ${ }^{30}$

The federal government has focused on preventing fraud and manipulation in commodity futures markets since futures trading first came under federal oversight in 1921 with the passage of The Futures Trading Act. ${ }^{31}$ Concerns around fraud and manipulation are grounded in the common law, which differentiates between futures contracts entered into for hedging purposes and those used for speculation (referred to in the common law as "difference contracts"). ${ }^{32}$ To differentiate between the two,

29. The CFTC's predecessor, the Commodity Exchange Authority, only regulated agricultural commodities enumerated in the Commodity Exchange Act. See CFTC, U.S. FUTURES TRAding and Regulation Before the Creation OF THE CFTC, https://cftc.gov/About/HistoryoftheCFTC/history_precftc.html (providing a history of commodity derivatives regulation).

30. 7 U.S.C. $\S 5(b)(2012)$.

31. The Futures Trading Act was found unconstitutional and replaced by the Grain Futures Act in 1922. See CFTC, supra note 29.

32. See, e.g., State v. Stripling, 113 Ala. 120, 123-24 (1896) (dictum) (stating that difference contracts have been "the source of great injury to morals"); Cunningham v. Nat'l Bank, 71 Ga. 400, 403-05 (1882) (stating that difference contracts are "fraught with . . . evil consequences" and are hence contrary to public policy); Rumsey v. Berry, 65 Me. 570, 574 (1876) (dictum) (emphasizing that difference contracts are "against public policy, and not only void, but deserving of the severest censure"); Cassard v. Hinmann, 14 How. Pr. 84, 90 91 (N.Y. Sup. Ct. 1856) (invalidating a difference contract under a law prohibiting betting and gaming for fear that speculative contracts would become "as common as legitimate dealing”); Brua's Appeal, 55 Pa. 294, 298-99 (1867) (holding invalid promissory notes for debts 
courts looked to the intent of the transaction-if one of the contracting parties owned or expected to own ("take delivery of") the underlying physical asset or commodity, then the contract was deemed to be entered into for hedging purposes and was therefore legally enforceable. ${ }^{33}$ On the other hand, a futures contract entered into for speculative purposesmeaning neither party owned or expected to own the underlying commodity - was deemed void and legally unenforceable. ${ }^{34}$

The courts recognized that futures speculation created incentives for contracting parties to manipulate the price of the underlying assets. In addition, courts considered derivatives speculation to be nothing more than rent-seeking behavior that wasted valuable human capital and increased aggregate risk. In this sense, derivatives speculation was thought of as a form of gambling that created unnecessary risks, not only for the contracting parties, but also for society as a whole. Such risks included: "bankruptcies, defalcations of public officers, embezzlements, forgeries, [and] larcenies." 35

Because the common law prohibited legal enforceability of speculative derivatives contracts, a system of "private ordering" emerged that allowed derivatives speculators to enforce their contracts by trading them on private venues. ${ }^{36}$ These private trading venues became the first commodity exchanges. Initially dominated by those with an economic interest in hedging a given commodity's price (farmers, merchants, millers), futures exchanges quickly became the domain of professional speculators, who were aided in their endeavors by the telegraph, which allowed them to easily place bets on future commodity price movements at venues across the country. ${ }^{37}$

While not enforceable by the courts, speculative futures contracts were enforced by the exchanges through the requirement that exchange members guarantee the performance of all exchange contracts. The exchanges ensured their members could uphold this guarantee by closely monitoring them and enforcing membership requirements such as

owed on a speculative contract on the grounds that "[a]ll gambling is immoral" and leads to misery and suffering).

33. See Lynn A. Stout, Derivatives and the Legal Origin of the 2008 Credit Crisis, 1 Harv. Bus. L. Rev. 1, 11 (2011).

34. Id.

35. Cunningham v. Nat'l Bank of Augusta, 71 Ga. 400, 403 (1882).

36. See Lynn A. Stout, Why the Law Hates Speculators: Regulation and Private Ordering in the Market for OTC Derivatives, 48 DuKE L. J. 701 (1999).

37. Stout, supra note 33, at 15. 
collateral, capital, and standardized contract terms. These early futures exchanges have been characterized as "private gambling clubs owned by sophisticated business parties with both the motive and the means to ensure that members in the club would make good on their bets." 38

Federal regulation of futures trading went through several iterations between the early 1920s and the establishment of the CFTC in $1974 .{ }^{39}$ In addition to authorizing the CFTC to regulate private commodity exchanges, the CEA also codified and hardened previous common law rules by strictly prohibiting trading in "off-exchange futures" (or "OTC derivatives"). ${ }^{40}$ This requirement meant that not only were off-exchange futures judicially unenforceable, but they were now illegal as well. ${ }^{41}$

\section{B. New Product Approval Pre-CFMA}

Futures exchanges establish rules that govern the terms and conditions of all futures contracts and the rights and duties of exchange members. Prior to 1936, exchanges were free to determine their own rules without government interference. ${ }^{42}$ Upon passage of the CEA in 1936, all exchange contract rules, and changes to existing rules, had to be submitted to the Commodity Exchange Commission (the "Commission"), which consisted of the Secretary of Agriculture, the Secretary of Commerce, and the Attorney General. Although exchanges were required to submit rule changes to the government, the government did not have a right to disapprove of these rules, provided certain conditions were met. ${ }^{43}$ With amendments to the CEA in 1968, the Secretary of Agriculture was given the authority to disapprove rules containing "terms and conditions in contracts of sale to be executed on or subject to the rules of such contract market or relate to other trading requirements."44 Philip McBride Johnson and Thomas Lee Hazen note that the legislative history of these

38. Stout, supra note 33 , at 16. tion).

39. See CFTC, supra note 29 (discussing the history of U.S. futures trading and regula-

40. There were exceptions to this prohibition for OTC "forward" contracts that were physically settled and presumed to serve a hedging purpose. See Stout, supra note 33, at 18.

41. Stout, supra note 33, at 18.

42. JoHnSON, ET AL., supra note 24, at 496.

43. For instance, the Grain Futures Act of 1922 required the contract markets to "provide" against manipulations, comers, false rumors, and denial of membership to qualified agricultural cooperatives, all of which was done through the adoption of rules. JOHNSON, ET AL., supra note 24 , at 496.

44. JOHNSON, ET AL., supra note 24, at 497. 
CEA amendments "suggests that this limiting language was incorporated for the purpose of distinguishing between market oriented rules and the many other rules adopted by exchanges to govern their internal, administrative, operational, or political life." ${ }^{45}$ Thus, it appears that Congress's intent was to give the Secretary of Agriculture the authority to review, and if necessary, disapprove, rules related to contract terms and conditions and not the administrative rules governing exchange member behavior. ${ }^{46}$

The Commodity Futures Trading Commission Act of 1974 transformed the new product approval regimen, amending the previous process (whereby a new contract could be disapproved of) to an affirmative process, whereby the CFTC had to approve new rules pertaining to the "terms and conditions in contracts of sale." "47 The amended CEA required the CFTC to process rule change requests within 180 days of submission and to approve proposed rules if they did not violate the CEA or the Commission's regulations. ${ }^{48}$ This process remained essentially unchanged until passage of the Commodity Futures Modernization Act ("CFMA") in 2000. ${ }^{49}$ Thus, from 1968 until 2000, the CFTC had the right to review, and disapprove of, contract market rules relating to "terms and conditions of sale." ${ }^{50}$ The CFTC did not define "terms and conditions of sale" until it adopted former Regulation section 1.41 in $1983 .{ }^{51}$ In that regulation, the CFTC defined "terms and conditions" as "any definition of the trading unit or the specific commodity underlying a contract for the future delivery of a commodity or commodity option contract, specification of settlement or delivery standards and procedures, and establishment of buyers' and sellers' rights and obligations under the contract." 52 Therefore, during the period of time when the CFTC reviewed proposed rule changes, rules that were operational or administrative in nature were

45. JOHNSON, ET AL., supra note 24, at 497.

46. Johnson and Hazen note that rules related to contract margin levels were excluded from review. JOHNSON, ET AL., supra note 24, at 498.

47. JoHnSON, ET AL., supra note 24, at 498 (both 1968 and 1974 amendments only applied to terms and conditions of contracts and not margin requirements or other rules governing member behavior).

48. The Act also required the CFTC to give notice of disapproval to the contract market and provide an opportunity for a hearing. JOHNSON, ET AL., supra note 24, at 498.

49. Commodities Futures Modernization Act of 2000, 7 U.S.C. $\$ 1$ (2000).

50. JOHNSON ET AL., supra note 24, at 500.

51. Contract Market Rule Review Procedures, 48 Fed. Reg. 49,003 (Oct. 24, 1983) (to be codified at 17 C.F.R. pt. 1).

52. 48 Fed. Reg. 49,008 (Oct. 24, 1983) (codified at 17 C.F.R. $§ 1.41(a)(2)$ (1984)). 
largely excluded from such review, including rules pertaining to margin levels. ${ }^{53}$

\section{The CFMA's Impact on New Product Approval}

The CFMA upended the previous system of new product approval by eliminating the pre-approval requirement and introducing a self-certification process that allows exchanges to place new rules into effect, including rules applicable to the terms and conditions of new contracts, almost immediately, provided the proposed rule adheres to CEA and CFTC regulations.

Self-certification allows designated contract markets ${ }^{54}$ ("DCMs") to list any new contract for trading, and approve any new rule or amendment, by providing a written certification to the CFTC that the new contract, rule, or rule amendment, complies with the CEA and CFTC regulations. ${ }^{55}$ Unless the CFTC finds the new product or rule change violates the CEA or CFTC regulations, the DCM may list the new product no sooner than one full business day following the self-certification. DCMs also have the option of voluntarily submitting new contracts for approval to the Commission.

The CFTC has established twenty-three core principles that must be met in order for an exchange to list a new contract. The core principles run the gamut from requiring exchanges to prevent manipulation in traded contracts to enforcing rules governing exchange member conduct. The CFTC has limited grounds for staying a new contract listing and may only do so when there are "novel or complex issues that require additional time to analyze, an inadequate explanation by the submitting registered entity, or a potential inconsistency" with the CEA or CFTC regulation. ${ }^{56}$

As shown in Figure 1, exchanges were initially hesitant to take advantage of self-certification. In 2000, nearly the same number of new products were launched by submitting them to the CFTC for approval (twenty-three) as were launched by self-certification (twenty-four). It wasn't until 2002 that exchanges began to make liberal use of the self-

53. JOHNSON ET AL., supra note 24, at 503.

54. Designated contract markets (DCMs) are exchanges that may list for trading futures or option contracts based on all types of commodities and that may allow access to their facilities by all types of traders, including retail customers. See Trading Organizations, CFTC, https://www.cftc.gov/IndustryOversight/TradingOrganizations/index.htm.

55. 7 U.S.C. $\S 7(a)(2)$.

56. Id. 
certification process, and the use of self-certification has continued to grow to the point where now, new contracts are introduced exclusively through self-certification.

Figure $1^{57}$

Number of Products Approved vs. Self-Certified (2000-2017)

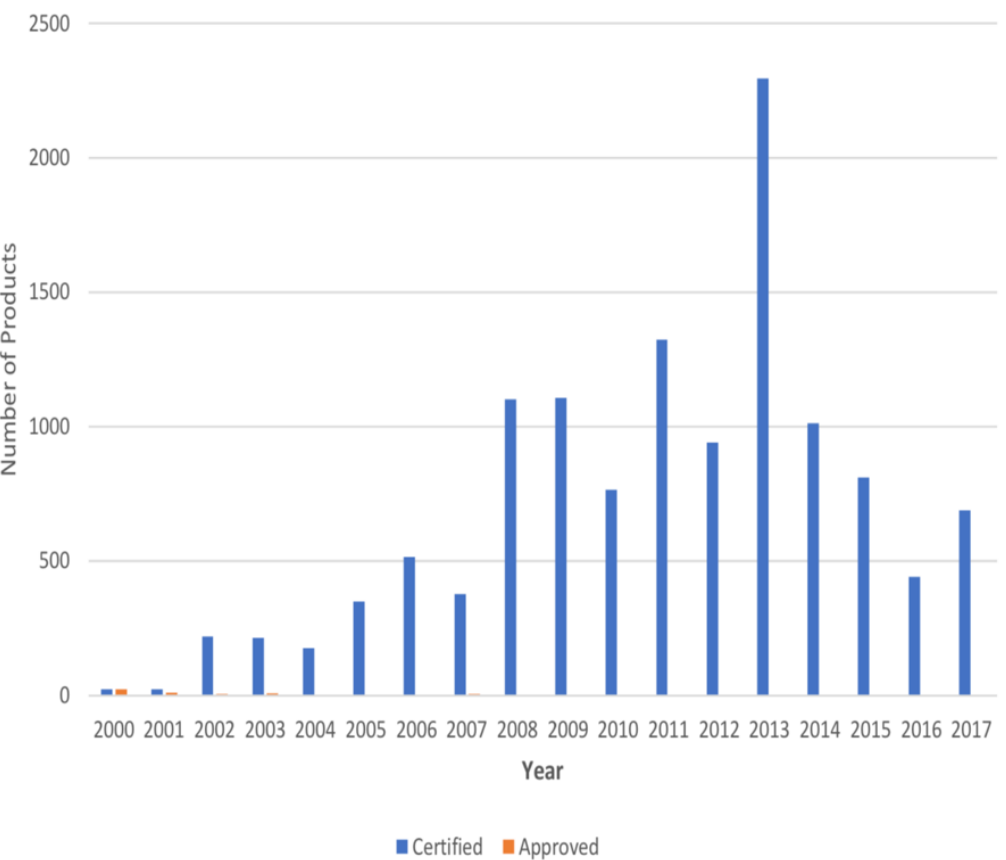

D. The CFMA's Legacy

The CFMA is commonly cited as a primary cause of the Global Financial Crisis (the "crisis"). ${ }^{58}$ This criticism has focused on the CFMA's liberalization of the OTC derivatives market, which included overturning the prohibition on OTC derivatives, which had been in place since 1974. After the CFMA's passage, the OTC derivatives market

57. The data in Figure 1 is compiled from a publicly available database on the CFTC's website. Trading Organization Products, CFTC, https://sirt.cftc.gov/sirt/sirt.aspx?Topic=TradingOrganizationProducts\&implicit=true\&Status $=$ Certified\&Custom ColumnDisplay $=$ TTTTTTTTT .

58. See Stout, supra note 33 at 22-27; Fin. CRISIS InQUiRy COMM'N, The FINANCIAL CRISIS INQUIRY REPORT: FINAL REPORT OF THE NATIONAL COMMISSION ON THE CAUSES OF THE FinANCIAL AND ECONOMIC CRISIS IN THE United STATES 48 (2011) https://www.gpo.gov/fdsys/pkg/GPO-FCIC/pdf/GPO-FCIC.pdf. 
quickly grew to the point where it posed a systemic risk. ${ }^{59}$ When U.S. home prices began to decline in 2006, the OTC derivatives market served as a channel by which this systemic risk spread to all corners of the financial system. While the scholarly literature has focused on the CFMA's role in deregulating OTC derivatives, little attention has been placed on how the legislation upended the new product approval process for commodity derivatives. ${ }^{60}$

It is clear from Figure 1 that the self-certification process facilitated the launch of many new kinds of exchange-traded commodity derivatives. These contracts may have been less risky than off-exchange (OTC) derivatives, but this does not mean that they were well-understood by those who traded them. Therefore, by allowing a flood of new exchange-traded derivatives to enter the market in the run-up to the crisis, the self-certification process played a role in fostering financial instability. ${ }^{61}$

While post-crisis reforms in the U.S. and other developed countries have reduced the risks associated with OTC derivatives by mandating central clearing and post-trade transparency, the self-certification process remains in place.

\section{E. The CFTC's Heightened Review of Bitcoin Futures}

The introduction of bitcoin futures brought fresh attention to the self-certification process, which had largely avoided academic and press scrutiny. Many market observers and commenters were surprised to learn that futures contracts on a new and unique asset like bitcoin could be brought to market with no public input and limited regulatory review. To provide more clarity on the self-certification process and federal oversight over virtual currency, the CFTC took the unusual step on January 4, 2018, of releasing a background document titled: "CFTC Backgrounder on Oversight of and Approach to Virtual Currency Futures Markets" (the "backgrounder"). ${ }^{62}$

59. At year-end 2000, when the CFMA was passed, the notional amount of OTC derivatives outstanding globally was $\$ 95.2$ trillion, and the gross market value was $\$ 3.2$ trillion. In the seven and one-half years from then until June 2008, when the market peaked, outstanding OTC derivatives increased more than sevenfold to a notional amount of $\$ 672.6$ trillion; their gross market value was \$20.3 trillion. See FIn. CRISIS INQUIRY COMM’N, supra note 58, at 48.

60. For a better understanding of how the CFMA transformed the new product approval process, see Saule T. Omarova, License to Deal: Mandatory Approval of Complex Financial Products, 90 WASH. U. L. Rev. 63 (2012).

61. The precise role the self-certification process played in contributing to the crisis is not known, but it is a question worthy of scholarly analysis.

62. Commodity Futures Trading COMm'n, CFTC BaCkgrounder on Oversight of and Approach to Virtual CurRency Futures Markets (Jan. 4, 2018), 
The CFTC acknowledged in the backgrounder that they have limited grounds to "stay" a self-certification and that in the case of CME's and CFE's self-certification of bitcoin futures contracts, these grounds were not met. The CFTC went on to defend their actions by stating: "[h]ad it even been possible, blocking self-certification would not have stemmed interest in Bitcoin or other virtual currencies nor their spectacular and volatile valuations. Instead, it would have ensured that the virtual currency spot markets continue to operate without federal regulatory surveillance for fraud and manipulation."63

The CFTC also acknowledged that they engaged with both exchanges in the period leading up to the self-certifications in a process they refer to as "heightened review." 64 Heightened review is a new process, without statutory basis, that the CFTC is using to review new virtual currency derivatives products. There is no mention of heightened review in CFTC documents or staff statements prior to release of the backgrounder, thus, heightened review appears to be a label the CFTC attached afterthe-fact to the process utilized with CME and CFE prior to the launch of their bitcoin futures contracts. The backgrounder lists seven specific elements to heightened review:

1. Derivatives clearing organizations ("DCOs") setting substantially high initial and maintenance margin for cash-settled bitcoin futures;

2. DCMs setting large trader reporting thresholds at five bitcoins or less;

3. DCMs entering direct or indirect information sharing agreements with spot market platforms to allow access to trade and trader data;

4. DCMs monitoring data from cash markets with respect to price settlements and other bitcoin prices more broadly, and identifying anomalies and disproportionate moves in the cash markets compare to the futures markets;

5. DCMs agreeing to engage in inquiries, including at the trade settlement level when necessary;

6. DCMs agreeing to regular coordination with CFTC surveillance staff on trade activities, including

https:/www.cftc.gov/sites/default/files/idc/groups/public/@newsroom/documents/file/backgrounder_virtualcurrency01.pdf.

63. Id. at 2 .

64. Id. at 3 . 
providing the CFTC surveillance team with trade settlement data upon request; and

7. DCMs coordinating product launches so that the CFTC's market surveillance branch can carefully monitor minute-by-minute developments. ${ }^{65}$

It is clear from the backgrounder and other public statements made by CFTC leadership, ${ }^{66}$ that the CFTC viewed the introduction of bitcoin futures contracts as a positive development. The primary benefit, according to the CFTC, is that by requiring CME and CFE to enter into information sharing agreements with bitcoin spot market platforms and share their market insights with the CFTC, the CFTC will have greater visibility into the bitcoin spot market, which they do have the authority to police for fraud and manipulation. However, bitcoin spot trading is diffuse, and the exchanges that are sharing information with CME and CFE represent a small portion of overall bitcoin spot trading. ${ }^{67}$ Therefore, the CFTC's visibility into bitcoin spot markets remains limited, and the introduction of bitcoin futures contracts may incentivize manipulative behavior in a spot market that is already ripe with manipulation.

\section{MANiPUlATION IN THE BITCOIN MARKET}

\section{A. Bitcoin Violates the Law of One Price}

The key regulatory hurdle CME and CFE needed to clear in listing their respective bitcoin futures contracts was the CFTC's Core Principle 3: "[t]he board of trade shall list on the contract market only contracts that are not readily susceptible to manipulation." 68 The ability to manipulate a cash-settled futures contract depends on how easily the reference rate that is used to price the contract can also be manipulated. For instance, a trader seeking to profit off a long position in a bitcoin futures contract could place a large trade in the bitcoin spot market on the contract's settlement date, thereby pushing up the price of bitcoin and earning a tidy profit on the futures position. ${ }^{69}$ This tactic, known as "banging the

65. $I d$.

66. See J. Christopher Giancarlo, Remarks to the ABA Derivatives and Futures Section Conference, Naples, Florida (Jan. 19, 2018), https://www.cftc.gov/PressRoom/SpeechesTestimony/opagiancarlo34.

67. These points will be made more explicit later in the Article.

68. 17 C.F.R. $\S 38.200$.

69. See, e.g., Alexander Osipovich, Bitcoin Futures Manipulation 101: How 'Banging the Close' Works, WALL ST. J. (Dec. 16, 2017), https://www.wsj.com/articles/bitcoin-futuresmanipulation-101-how-banging-the-close-works-1513425600. 
close," has a long history in futures markets ${ }^{70}$ and has played a central role in several recent high-profile market manipulation scandals. ${ }^{71}$

Establishing the reference rate for most cash-settled futures contracts is relatively straightforward; the value of an S\&P 500 futures contract is simply determined by the level of the S\&P 500 index. However, determining the reference rate for bitcoin futures is challenging because bitcoin violates the "law of one price" — an economic principle wherein the price of an identical security or commodity should have the same price regardless of where it is traded. If you were to look up the price of bitcoin on five different exchanges, you would likely see five different prices. According to this law, price discrepancies should be eliminated by arbitrageurs buying bitcoin on the lowest priced exchange and selling it on the highest. In 2016, researchers from the Federal Reserve Bank of New York looked into why bitcoin violates the law of one price and came up with several answers. ${ }^{72}$ One partial explanation is that bitcoin exchanges charge high trading fees, and sometimes fees for depositing or withdrawing fiat currency, and these fees eat into arbitrage profits. The researchers also found that on certain exchanges, it took five to ten days to deposit U.S. dollars into a user's account; should a trader seek to exploit an arbitrage opportunity by trading on an online exchange, they may not be able to execute their trade before the price of bitcoin moves against them. ${ }^{73}$ To avoid this risk, traders can pre-fund their bitcoin exchange accounts, but this exposes them to the risk that the exchanges may be hacked and their funds stolen.

Because bitcoin lacks a universal price, CME and CFE needed to develop a reference rate for bitcoin futures that was resistant to manipulation. In their self-certifications, both exchanges spent a considerable amount of time explaining the construction and features of their reference rate and why they believe it cannot be manipulated. ${ }^{74}$

70. See, e.g., Craig Pirrong, Manipulation of Cash-Settled Futures Contracts, 74 J. Bus. $221(2001)$.

71. This includes the foreign exchange market and LIBOR.

72. Alexander Kroeger \& Asani Sarkar, Is Bitcoin Really Frictionless?, LIBERTY ST. ECON. (March 23, 2016), http://libertystreeteconomics.newyorkfed.org/2016/03/is-bitcoinreally-frictionless.html.

73. The researchers also found delays in the time it took to move bitcoin between various exchanges. Id.

74. See Certification Letter from Christopher Bowen, Managing Director \& Chief Reg. Couns., Chicago Exchange, Inc., to Christopher J. Kirkpatrick, CFTC Secretary, 5 (Dec. 1, 2017), https://www.cftc.gov/sites/default/files/filings/ptc/17/12/ptc120117cmedcm001.pdf; Product Certification Letter from Cboe to Christopher J. Kirkpatrick, CFTC Secretary 2 (Dec. 1, 2017), https://www.cftc.gov/sites/default/files/filings/ptc/17/12/ptc120117cfedcm001.pdf. 


\section{B. CME Reference Rate Constituent Exchanges}

The CME bitcoin futures contract utilizes the Bitcoin Reference Rate ("BRR") as the unit of trade. The BRR is administered by Crypto Facilities Ltd. ("CF") ${ }^{75}$ and is governed by an oversight committee (the "Committee"). According to Crypto Facilities, "[t]he role of the Oversight Committee is to provide an oversight function to review and provide challenge on all aspects of the methodology and calculation process and provide effective oversight of $\mathrm{CF}$ as the administrator of the Cryptocurrency Pricing Products." 76 CME has significant influence over the Committee because they hold two of the seven seats, including the chairmanship. The remaining Committee members include one representative from Crypto Facilities and four independent bitcoin experts. ${ }^{77}$ Any member of the Committee may be removed, with or without cause, jointly by $\mathrm{CF}$ and $\mathrm{CME}{ }^{78}$

As of October 11, 2018, the BRR is calculated based upon bitcoin transactions in U.S. dollars on four different exchanges: Bitstamp, GDAX, Itbit and Kraken (the "Constituent Exchanges"). In their certification, CME lists seven criteria that must be met for an exchange to become a BRR Constituent Exchange. ${ }^{79}$ This includes a requirement that each exchange must account for at least $3 \%$ of total bitcoin versus U.S. dollar spot trading volume occurring on all Constituent Exchanges combined during each of the last two consecutive calendar quarters. ${ }^{80}$

75. Crypto Facilities was purchased by virtual currency exchange Kraken on February 4, 2019. Crypto Facilities will remain London-based and be subject to oversight by the United Kingdom's Financial Conduct Authority. Press Release from Crypto Facilities, Kraken Acquires Crypto Derivatives Trading Platform and Index Provider, Crypto Facilities, in Ninefigure deal, (Feb. 4, 2019), https://www.cryptofacilities.com/cryptocurrency-news/crypto-facilities-acquired-by-kraken.

76. Crypto Facilities Ltd., CME CF Cryptocurrency Pricing Products Oversight COMmittee (June 7, 2018), https://www.cryptofacilities.com/cms/storage/resources/phpeqL79X.pdf.

77. In their self-certification CME states that the Committee meets once per quarter but the meeting minutes posted to CME's and CF's websites indicate that the first meeting in 2018 didn't occur until July. In 2017, the Committee did meet on a quarterly basis. See CRYPTO FACILITIES LTD., https://www.cryptofacilities.com/indices/XBT/USD/RR/days (last visited Jan. 11, 2019) (the site contains a list of all previous meeting minutes).

78. CRYPTO FACILITIES LTD., supra note 76.

79. Bowen, supra note 74.

80. The 3\% volume criterion is not listed in the Committee's "Constituent Exchange Criteria" document but a representative from Crypto Facilities assured me via email that the minimum required volume contribution for any exchange to become eligible for potential inclusion is $3 \%$ of the combined total of all the existing exchanges and this information will be reflected in the next update to the "Constituent Exchange Criteria" document, which as of January 11, 2019, has yet to occur. See CRYPTO FACILITIES LtD., CME CF CRYPTOCURRENCY Pricing Products: Constituent ExChanges CRiteria (May 2018), https://www.cryptofacilities.com/cms/storage/resources/phpPo5sVo.pdf. 
In their certification, CME notes two additional Constituent Exchanges, Bitfinex and OkCoin, are temporarily suspended from contributing to the BRR due to "fiat transfer restrictions." minutes from the September 2017 meeting indicate Bitfinex and OkCoin were "removed from the BRR in April 2017 due to transfer restrictions" which "currently persist." 82 While neither CME's certification, nor the Committee minutes, elaborate on what is meant by "transfer restrictions," there are numerous news articles from April 2017 that detail the difficulty Bitfinex and OKCoin customers were having in moving fiat currency into, and out of, their exchange accounts. In April 2017, Bitfinex released the following statement: "Beginning April 18, 2017, all incoming wires to Bitfinex will be blocked and refused by our Taiwan banks. This applies to all fiat currencies at the present time. Accordingly, we ask customers to avoid sending incoming wires to us until further notice, effective immediately." ${ }^{83}$ OKCoin experienced a similar issue around the same time with their Taiwan-based intermediary banks. ${ }^{84}$

Bitfinex and OKCoin are two of the four largest bitcoin exchanges by dollar trading volume; ${ }^{85}$ therefore, including both exchanges in the calculation of the BRR would help foster price discovery. However, there is no mention of either exchange in the December 2017 or July 2018 Committee minutes, so we can only speculate as to why they remain suspended from contributing to the BRR. While Bitfinex customers continue to experience delays with fiat currency withdrawals, ${ }^{86}$ OKCoin appears to have cleared up their transfer restriction issues.

Beyond the transfer restrictions, both exchanges have experienced serious problems that have generated negative press coverage, much of which was publicly known when CME submitted their certification. Bitfinex has an especially troubled past. In 2016, hackers stole $\$ 72$

81. Bowen, supra note 74.

82. Crypto Facilities Ltd., CME CF Oversight Committee Minutes Sep 2017 (Sept. 7, 2017), https://www.cryptofacilities.com/cms/storage/resources/phpnmQarW.pdf.

83. Andrew Saks-McLeod, Instability at Bitfinex Reinforces FinaneFeeds View that Bitcoin Will Never be a Financial Mainstay, FinANCEFEEDS (April 18, 2017), https://financefeeds.com/instability-bitfinex-reinforces-financefeeds-view-bitcoin-will-never-financial-mainstay/.

84. See Samburaj Das, After Bitfinex, Chinese Bitcoin Exchange OKCoin Suspends Wire Transfers, CCN (April 19, 2017), https://www.ccn.com/bitcoin-exchange-okcoin-suspendswires/.

85. Obtaining accurate data on bitcoin trading volume is difficult. My main source for trading volume data is www.data.bitcoinity.org but for whatever reason they do not list volume data for OKCoin or its subsidiary, OKEx. OKEx trading volume can be found at: Top 100 Cryptocurrency Exchanges by Trade Volume, COINMARKETCAP https://coinmarketcap.com/rankings/exchanges/ (last visited Nov. 8, 2018).

86. See David Floyd \& Nikhilesh De, For Bitfinex Users, Dollar Withdrawals Are Now a Weeks-Long Struggle, CoINDESK (Nov. 9, 2018), https://www.coindesk.com/for-bitfinexusers-dollar-withdrawals-are-now-a-weeks-long-struggle/. 
million worth of bitcoin from Bitfinex, ${ }^{87}$ just fifteen months after a different hack resulted in the theft of 1,500 bitcoins from the exchange. ${ }^{88}$ Bitfinex has also run afoul of applicable U.S. regulation. In 2016, the CFTC reached a settlement with Bitfinex over their practice of letting U.S. customers borrow funds from other users on the platform in order to trade bitcoins on a leveraged basis. ${ }^{89}$ Because Bitfinex was not a registered exchange with the CFTC, and because the purchased bitcoins were never delivered to the purchasers but were held in deposit wallets owned and controlled by Bitfinex, the exchange was in violation of sections 4(a) and $4 \mathrm{~d}$ of the CEA. ${ }^{90}$

Perhaps the most troubling aspect of Bitfinex is its association with the virtual currency Tether. Tether was established by the owners of Bitfinex and the two companies share a CEO. ${ }^{91}$ Tether's value is pegged directly to the U.S. dollar, which the company claims is accomplished by keeping U.S. dollars equal to the market value of all Tether in circulation in reserve at all times. This claim has been under serious doubt for some time, and Tether has yet to provide any audited statements confirming the existence of U.S. dollar reserves. ${ }^{92}$ They did attempt an audit to support their dollar reserve claim, but subsequently fired their auditor before a final report could be released. ${ }^{93}$

87. Clare Baldwin, Bitcoin Worth $\$ 72$ Million Stolen from Bitfinex Exchange in Hong Kong, REUTERS (Aug. 3, 2016), https://www.reuters.com/article/us-bitfinex-hackedhongkong/bitcoin-worth-72-million-stolen-from-bitfinex-exchange-in-hong-kongidUSKCN10E0KP.

88. Allen Scott, BitFinex's Hot Wallet Hacked, More than 1,500 Bitcoins Stolen, COINTELEGRAPH (May 22, 2015), https://cointelegraph.com/news/breaking-bitfinex-hot-wallet-hacked-bitcoins-stolen.

89. BFXNA, Inc., CFTC No. 16-19, 2016 (June 2, 2016). https://www.cftc.gov/sites/default/files/idc/groups/public/@1renforcementactions/documents/legalpleading/enfbfxnaorder060216.pdf.

90. Id. at 1.

91. See Sarit Markovich, Commentary: The Overlooked Actor that Could Crash Bitcoin, FORTUNE (Dec. 5, 2017), http://fortune.com/2017/12/05/bitcoin-btc-price-usd-tether-limitedbitfinex/; Nathaniel Popper, Warning Signs About Another Giant Bitcoin Exchange, N.Y. Times (Nov. 21, 2017), https://www.nytimes.com/2017/11/21/technology/bitcoin-bitfinextether.html.

92. On November 1st, 2018, Deltec Bank \& Trust in the Bahamas issued a letter that claimed Tether held over $\$ 1.8$ billion in reserves at the bank. The letter was widely scrutinized and there remains considerable doubt that Tether is holding adequate, or any, dollar reserves. See David Floyd, Deltec Chairman Says Tether Letter on Bank Relationship Is 'Authentic', COINDESK (Nov. 5, 2018), https://www.coindesk.com/deltec-chairman-says-tether-letter-onbank-relationship-is-authentic/.

93. See Paul Vigna \& Steven Russolillo, The Mystery Behind Tether, the Crypto World's Digital Dollar, WaLl ST. J. (Aug. 12, 2018), https://www.wsj.com/articles/the-mystery-behind-tether-the-crypto-worlds-digital-dollar-1534089601. 
Beginning in April 2017, a pseudonymous character known as "Bitfinex'ed" began making credible ${ }^{94}$ claims on social media and in blog posts that Bitfinex was creating Tether out of thin air and using Tether to push up the price of Bitcoin. Recall that April 2017 was also when Bitfinex was suspended from contributing to the BRR calculation, although the stated reason was due to transfer restrictions. Bitfinex'ed's allegations against Bitfinex picked up steam throughout 2017 and by the end of the year, stories alleging that Bitfinex was using Tether to push up bitcoin's price appeared in mainstream publications, including The New York Times and Forbes. ${ }^{95}$

All of this was widely known by the time CME submitted their certification on December 1, 2017. While the certification makes clear that Bitfinex was "temporarily suspended" from contributing to the BRR, it makes no mention of Bitfinex's past problems. In fact, the certification seems to imply that Bitfinex will contribute to the BRR calculation once the "transfer restrictions" issue is resolved.

The mention of Bitfinex as a possible BRR Constituent Exchange should have been a red flag when the CFTC reviewed the certification. While there is no record of the CFTC expressing concern around the potential for Bitfinex to be involved in the BRR calculation, the CFTC was apparently interested in the role Bifinex and Tether may have played in manipulating bitcoin's price. In January 2018, Bloomberg reported that the CFTC sent subpoenas on December 6, 2017, to Bitfinex and Tether. ${ }^{96}$

Bitfinex'ed's allegations were effectively proven in June 2018, when John Griffin and Amin Shams from the University of Texas-Austin analyzed data from the bitcoin and Tether blockchains and found that Tether had been used by entities associated with Bitfinex to prop up the price of bitcoin during periods when the price was declining. ${ }^{97}$ Griffin and Shams note that their findings provide "substantial support for the view that price manipulation may be behind substantial distortive effects in cryptocurrencies." ${ }^{98}$ Griffin and Shams findings were given additional weight when it was reported in November 2018, that the U.S. Justice

94. Several of Bitfinex'ed's claims have been independently verified. Specifically, the charge that Bitfinex was using Tether to prop up the prince of bitcoin. For more information on Bitfinex'ed, see Lawrence Lewitinn, Bitfinex'ed Tells (Almost) All About Tether: The Modern Consensus Interview, MOdern CONSENSus (Oct. 17, 2018), https://modernconsensus.com/cryptocurrencies/tether/bitfinexed-interview-tether-bitfinex/.

95. Markovich, supra note 91; Popper, supra note 91.

96. Matthew Leising, U.S. Regulators Subpoena Crypto Exchange Bitfinex, Tether, BLOOMBERG (Jan. 30, 2018), https://www.bloomberg.com/news/articles/2018-0130/crypto-exchange-bitfinex-tether-said-to-get-subpoenaed-by-cftc.

97. Griffin \& Shams, supra note 27.

98. Griffin \& Shams, supra note 27, at 33. 
Department was investigating Tether and Bitfinex for possible market manipulation. ${ }^{99}$

\section{BRR Methodology}

In their certification, CME states that the BRR "is in accordance with market best practices and IOSCO [(International Organization of Securities Commissions)] principles," yet they provide no detail on what these principles are or evidence that attests to their compliance. ${ }^{100}$ IOSCO's "Principles for Financial Benchmarks" were released in July 2013, well before Bitcoin was on IOSCO's radar. ${ }^{101}$ Furthermore, it does not appear that the BRR is in compliance with all nineteen principles. Principle 17 requires the benchmark administrator to appoint an "independent internal or external auditor with appropriate experience and capability to periodically review and report on the Administrator's adherence to its stated criteria and with the Principles." ${ }^{102}$ There is no evidence that $\mathrm{CME}, \mathrm{CF}$, or the Committee conducted an independent audit of the BRR.

CME believes the methodology used to calculate the BRR prevents any kind of manipulation. ${ }^{103}$ The BRR is calculated daily and is based upon all bitcoin trades in U.S. dollars from 3:00 PM to 4:00 PM London time, across the four Constituent Exchanges. ${ }^{104}$ The calculation methodology for the BRR is as follows:

1. All Relevant Transactions are added to a joint list, recording the trade price and size for each transaction;

2. The list is partitioned into twelve equally-sized time intervals of five minutes each;

3. For each partition separately, the volume-weighted median trade price is calculated from trades submitted by each exchange; and

99. See Matt Robinson \& Tom Schoenberg, Bitcoin-Rigging Criminal Probe Focused on Tie to Tether, BlOOMBERG (Nov. 20, 2018), https://www.bloomberg.com/news/articles/201811-20/bitcoin-rigging-criminal-probe-is-said-to-focus-on-tie-to-tether.

100. Bowen, supra note 74, at 5.

101. Int'L Org. Sec. Comm'n, Principles for Financial Benchmarks, Report 8 (July 2013), http://www.iosco.org/library/pubdocs/pdf/IOSCOPD415.pdf.

102. Id. at 28 .

103. Bowen, supra note 74, at 5.

104. The trades are reported through each constituent exchange's API to Crypto Facilities. See Bowen, supra note 74, at 5. 
4. The BRR is then calculated as the equally-weighted average of the volume weighted medians of all partitions. ${ }^{105}$

In their certification, CME claims the BRR is resistant to manipulation: "[T]he index is calculated from a large number of trades observed during the calculation window. The combination of volume weighting of medians plus non-weighted partitions prevents manipulation in the reference rate. Ultimately, influencing the BRR would require significant trading activity on several exchanges over an extended period of time." 106

To support their claim that the BRR cannot be manipulated, the CF and CME websites include a paper written in October 2016 by William J. Knottenbelt, Professor of Applied Quantitative Analysis at Imperial College London, and his former student, Andrew Paine, titled "Analysis of the CME CF Bitcoin Reference Rate and Real Time Index."107 Knottenbelt and Pain conclude that " $\mathrm{t}]$ he chosen specification makes the BRR highly resistant against manipulation."108 It should be noted that Knottenbelt also serves on the BRR Oversight Committee.

\section{CFE Reference Rate}

The CFE Bitcoin Futures Contract ("XBT") is based on the auction price of Bitcoin in U.S. dollars on the 4 PM EST Gemini Exchange. Gemini is a full reserve exchange - meaning that all orders must be fully pre-funded with assets on deposit at the exchange. Because Gemini holds customer assets (both fiat and virtual currency) they sought, and received, a limited purpose trust company charter from the New York State Department of Financial Services ("NYDFS") in 2015. As a condition of licensure, Gemini is expected to comply with all the requirements of the NYDFS BitLicense regulatory framework, which was finalized in June 2015. ${ }^{109}$ The BitLicense is a first in the nation licensing regime specifically for virtual currency businesses that are based in New York or serve New York customers. In the press release announcing the grant of Gemini's charter, NYDFS noted that they conducted a "rigorous review" of Gemini's application, which included a review of Gemini's "anti-money

105. Bowen, supra note 74 , at 5.

106. Bowen, supra note 74, at 8 .

107. Andrew Paine \& William J. Knottnbelt, Analysis of the CME CF Bitcoin Reference Rate and Real Time Index, IMPERIAL C. CTR. CRYPTOCURRENCY Res. \& ENGINEERING 3 (Oct. 20, 2016), https://www.cmegroup.com/trading/files/bitcoin-white-paper.pdf.

108. Id. at 3.

109. BitLicense Regulatory Framework, 23 NYCRR Part 200 Virtual currencies (2015), https://www.dfs.ny.gov/legal/regulations/adoptions/dfsp200t.pdf. 
laundering, capitalization, consumer protection, and cyber security standards." $" 110$

The Gemini auction price is determined by "finding the price at which the greatest aggregate buy demand and sell demand from all eligible orders can be fulfilled; all continuous trading orders and auction-only orders are considered. The auction price then applies to all fills, allocated based on price-time priority."111 Like CME, CFE's certification emphasizes specific qualities of the Gemini exchange and auction process that make it difficult to manipulate the XBT contract. The most convincing argument they make is that all Gemini orders, including auction orders, must be pre-funded. Presumably, a would-be manipulator would not go through the hassle of creating an account at Gemini-which requires a user to verify their identity - and then deposit fiat currency or bitcoin into their Gemini account, just so they could influence the Gemini auction price (if they did, it would be easy to spot).

While it may be difficult to manipulate the Gemini auction price, Gemini's low trading volume hampers price discovery for bitcoin and could potentially lead to settlement failure in the XBT contract. In their certification, CFE states that on "August 28, 2017[,] the 20-day moving average of the Gemini Exchange's market share in exchange trading in bitcoin in U.S. dollars was $12.8 \%$." Considering their certification was filed on December 1, 2017, the reference to volume data on August 28 appears arbitrary. Time-series volume data from data.bitcoinity.org ${ }^{112}$ indicates that the August date may have been cherry-picked. The site does not list 20-day moving averages, but historical data for the 30-day moving average reveals that Gemini's peak trading volume as a share of the market in USD, occurred in July ( 15\%) and August ( 13\%) of 2017. Trading volume on Gemini has steadily declined since then. On December 1, 2017, Gemini accounted for just 7\% of the previous 30-days of bitcoin trading volume in USD, and that number has continued to come down, reaching 4.37\% on October 11, 2018.

In addition to low trading volume on Gemini, the 4 PM auction volume is also disturbingly low. In fact, on many days, the auction clears no bitcoin-auction failure occurred six times in September 2018 alone. ${ }^{113}$ If the Gemini auction were to fail on the final settlement date

110. Press Release from New York State Department of Financial Services, NYDFS Grants Charter to "Gemini" Bitcoin Exchange Founded by Cameron and Tyler Winklevoss (Oct. 5, 2015), https://www.dfs.ny.gov/about/press/pr1510051.htm.

111. Product Certification Letter from Cboe, supra note 74, at 2

112. This is the same data source that is cited by CFE to highlight Gemini trading volume in their submission. Product Certification Letter from Cboe, supra note 74, at 3.

113. Gemini's Daily Action Data, GEMINI, https:/gemini.com/auction-data/?currentPage $=2 \&$ startIndex $=1 \&$ filter=4PM-BTC-USD\#auctionData (last visited Nov. 8, 2018). 
for a XBT contract, it would cause significant disruption because the contract's settlement value could not be readily determined. ${ }^{114}$ So far, this has not happened, and should the auction fail on a contract settlement date, CFE would resort to the waterfall of possibilities listed in the contract specifications for determining final settlement value. ${ }^{115}$ Gemini has been publishing their auction data since 2016, and the data reveals numerous auction failures since then (including many before CFE filed their certification on December 1, 2017). Yet, there is no indication the CFTC expressed concern around Gemini auction volume.

\section{E. Manipulation in the Bitcoin Spot Market}

$\mathrm{CME}$ and CFE took great care to construct a reference rate for bitcoin that is resistant to manipulation. Assessing the feasibility of reference rate manipulation is beyond the scope of this Article, but it is worth noting there have been no reported instances of manipulation to date. However, evidence of manipulation in bitcoin spot markets is quite clear.

While Bitfinex's use of Tether may account for much of the 2017 run-up in bitcoin's price, many of the more volatile days in bitcoin's short history can be attributed to hacks at virtual currency exchanges. According to the Wall Street Journal, since 2011, there have been fifty-six virtual currency exchange cyberattacks, resulting in $\$ 1.63$ billion in losses. ${ }^{116}$ After each major hack, the price of bitcoin price dropped precipitously. There have also been several reports of manipulative trading practices in bitcoin spot markets, much of it driven by automated trading programs, or "bots.", 117

In September 2018, the New York State Office of the Attorney General (the "OAG") released the "Virtual Markets Integrity Report" (the "Report") which looked into the transparency, fairness, and security of

114. Auction failure is only a problem when it occurs on a contract settlement date. For all other days, the settlement value of bitcoin futures contracts is determined by the midpoint of the final bid and offer in each respective futures maturity. See E-mail from Michael Mollet, Dir. of Prod. Dev., Cboe Global Markets, to Lee Reiners, Ex. Dir., Global Financial Markets Center (Aug. 18, 2018, 10:07 EST) (on file with author).

115. See, CBOE, Summary Product Specifications Chart for Cboe Bitcoin (USD) FUTURES, http://cfe.cboe.com/cfe-products/xbt-cboe-bitcoin-futures/contract-specifications (the contingencies section details how final settlement value will be determined in the event normal settlement procedures cannot be utilized).

116. Steven Russolillo \& Eun-Young Jeong, Cryptocurrency Exchanges are Getting Hacked Because it's Easy, WALL ST. J. (July 16, 2018), https:/www.wsj.com/articles/whycryptocurrency-exchange-hacks-keep-happening-1531656000.

117. Paul Vigna \& Alexander Osipovich, Bots are Manipulating Prices of Bitcoin in 'Wild West of Crypto', WALL ST. J. (Oct. 2, 2018), https://www.wsj.com/articles/the-bots-manipulating-bitcoins-price-1538481600. 
virtual asset trading platforms. ${ }^{118}$ The Report found that the virtual currency industry does not have "serious market surveillance capacities, akin to those of traditional trading venues, to detect and punish suspicious trading activity." 119 The Report also noted that few of the virtual currency exchanges that responded to the OAG's questions have formal policies in place that define "the types of conduct the platform believes to be manipulative or abusive, and outlining how such trading behavior is to be detected and penalized."

Furthermore, it has become increasingly clear that much of bitcoin's value - outside of mere speculation - is derived solely from its ability to facilitate criminal activity. In July of 2018, special counsel Robert Mueller indicted twelve Russian intelligence officials for allegedly attempting to influence U.S. elections in $2016 .{ }^{120}$ The indictment notes that the conspirators used bitcoin to fund the purchase of servers, register domains, and make other payments "in furtherance of hacking activity." "According to the indictment, the "use of bitcoin allowed the Conspirators to avoid direct relationships with traditional financial institutions, allowing them to evade greater scrutiny of their identities and sources of funds." 122

Remarkably, the CFTC publicly acknowledged their indifference to fraud and manipulation in the bitcoin spot market. Speaking at the January 2018 meeting of the CFTC's Market Risk Advisory Committee ("MRAC"), Amir Zaidi, director of the CFTC's Division of Market Oversight ("DMO"), stated:

it is not the responsibility of DCMs [(derivatives clearing merchants)] or the CFTC to oversee on a daily basis every cash commodity market or make suitability judgments about the underlying commodity market and whether a futures contract should be able to be listed on it. Rightly, we are not overseeing cash markets and participants on a daily basis for abusive practices and risks. Every cash market underlying futures contracts can be manipulated. Gold, silver, FX, bitcoin cash markets, they can all be manipulated. However, making detailed judgments about

118. N.Y. ATt'y GEN., ViRTUAL MARKETS INTEGRITY REPORT (Sept. 18, 2018), https://virtualmarkets.ag.ny.gov/.

119. Id.

120. Indictment, United State v. Netyksho, No. 1:18-cr-00215-ABJ (July 13, 2018), https://www.justice.gov/file/1080281/download.

121. Id. at 21

122. Id. at 22 . 
the level of manipulation, generally, in those cash markets, and if it is too little or too much to list a futures contract, is a different analysis from whether a futures contract is readily susceptible to manipulation. ${ }^{123}$

In reviewing CME's and CFE's self-certifications, the CFTC made clear that their sole focus was on the potential to manipulate the contracts in question. At the same MRAC meeting, Zaidi noted that "DMO's analysis of whether a contract is readily susceptible to manipulation from a futures contract listing standpoint, always ties back to the integrity of the futures contract and the settlement process." 124 The integrity of bitcoin futures contracts depends on the integrity of their reference rate; this is why CME and CFE, along with their constituent exchanges, expended significant effort in designing, implementing, and explaining their respective reference rates. However, if the entire bitcoin spot market can be manipulated, can a futures contract based on bitcoin truly be resistant to manipulation? By not intervening to halt the self-certifications, the CFTC seems to think it can.

\section{F. $\quad$ The SEC Rejects the Winklevoss Bitcoin Trust}

The SEC does not share the CFTC's indifference to manipulation in the bitcoin spot market, as they have repeatedly cited concerns over manipulability as a reason for rejecting applications to list bitcoin related exchange traded products ("ETPs"). ${ }^{125}$ The SEC first rejected a bitcoin ETP in 2017, when it disapproved ${ }^{126}$ the Bats BZX Exchange Incorporated's ("BZX") proposed rule change ${ }^{127}$ to list and trade shares of the

123. CFTC, Transcript of Market Risk Advisory Committee Meeting (Jan. 31 2018), https://www.cftc.gov/sites/default/files/2018-08/mrac_013118_transcript.pdf [hereinafter Transcript of Market Risk Advisory Committee MeEting].

124. Id at 45 .

125. This concern was most recently expressed by SEC Chairman Jay Clayton on November 27, 2018, when he stated that concerns over market manipulation need to be addressed before a cryptocurrency ETF is approved. See Nikhilesh De, SEC Chair Clayton: Crypto ETF Needs Exchanges 'Free From Manipulation', COINDESK (Nov. 27, 2018), https://www.coindesk.com/clayton-sec-ico-funding-security-offering ( "How that [manipulation] issue gets addressed, I don't have a particular path. But it needs to be addressed' before an ETF gets approved, Clayton remarked during CoinDesk's Consensus: Invest conference.").

126. SEC Disapproval Order, supra note 28.

127. Section 19(b) of the Securities Exchange Act Of 1934 requires the exchange seeking to list the ETF to submit a proposed rule change to the SEC, which is then released for public comment. 15 U.S.C. $\S 78 \mathrm{~s}($ b) (2012). 
Winklevoss Bitcoin Trust ("Trust"). ${ }^{128}$ The Trust would hold bitcoins as an asset, and the bitcoins would be in the custody of, and secured by, the Trust's custodian, Gemini Trust Company LLC ("Custodian"). The Trust would issue and redeem shares ${ }^{129}$ that would track the price of bitcoin on the Gemini Exchange. ${ }^{130}$

BZX filed a petition ${ }^{131}$ to have the ruling reviewed by the SEC, which the SEC granted and then sought public comments in support of, or in opposition to, the original order. Many market observers believed the review would result in a favorable outcome for BZX due to further maturation in the bitcoin market since their original filing, as well as the introduction of bitcoin futures contracts. However, the SEC once again disapproved $^{132}$ the proposed rule change due to its finding that the proposal did not comply with the Securities Exchange Act of 1934 ("Exchange Act") Section 6(b)(5), which, among other requirements, stipulates that the rules of a national securities exchange be designed "to prevent fraudulent and manipulative acts and practices" and "to protect investors and the public interest." 133

In their amended proposal, BZX highlighted multiple features of the bitcoin market and the Trust that make manipulation unlikely, all of which the SEC found unpersuasive. BZX argued that the large number of bitcoin trading venues, and continuous trading on these venues, make it difficult to manipulate bitcoin because "there is no single market-close for investors to attempt to manipulate." 134 The SEC disagreed, and also found the argument irrelevant because the value of the Trust's shares would be based off a single market-close event, the 4 PM EST Gemini

128. Any sort of investment vehicle that holds virtual currency and offers ownership interests in the vehicle will be considered a security subject to SEC registration unless it meets SEC exemption requirements. This is why the SEC must sign off before any sort of bitcoin, or other virtual currency, Exchange Traded Fund can enter the market. See SEC, STATEMENT ON Digital ASSET SEcurities Issuance AND Trading (2018), https://www.sec.gov/news/public-statement/digital-asset-securites-issuuance-and-trading (discussing the registration requirements for initial offers and sales of digital asset securities, pooled investment vehicles investing in digital asset securities, and secondary markets trading in digital asset securities).

129. The Trust would issue and redeem the Shares only in "Baskets" of 100,000 shares and only to "Authorized Participants," and these transactions would be conducted "in-kind" for bitcoin only. SEC Disapproval Order, supra note 28, at 3.

130. SEC Disapproval Order, supra note 28, at 4.

131. Petition for Review, SR-BatsBZX-2016-30, Exchange Act Release No. 80206 (Mar. 25, 2017), https://www.sec.gov/rules/sro/batsbzx/2017/petition-for-review-sr-batsbzx-201630.pdf.

132. Self-Regulatory Organizations, Exchange Act Release No. 34-83723 20 (July 26, 2018) https://www.sec.gov/rules/other/2018/34-83723.pdf [hereinafter SEC Release No. 3483723].

133. 15 U.S.C. $\S 78 f(b)(5)$ (2009).

134. SEC Release No. 34-83723, supra note 132, at 20. 
auction - the same auction used to determine the settlement value of CFE bitcoin futures contracts. ${ }^{135}$ Acknowledging that Trust investors would have an incentive to manipulate the Gemini auction, the SEC expressed doubts that the Gemini auction would facilitate price discovery because:

(a) there is no comprehensive and accurate regulatory data source reflecting bitcoin pricing or trading; (b) there is no basis to conclude that the Trust's IIV [(Intraday Indicative Value)] ${ }^{136}$ would be considered an authoritative price when several other spot prices for bitcoin are already disseminated and often differ from one another; and (c) the Trust's NAV [Net Asset Value] would differ from the Gemini Auction price only if the auction price, which is publicly disseminated itself, is determined not to reflect a fair price for bitcoin. ${ }^{137}$

The SEC also expressed concern over the low trading volume on Gemini. Historically, when an exchange attempts to list an exchange traded product in a market that is "not demonstrably resistant to manipulation," 138 the SEC requires comprehensive surveillance sharing agreements between the exchange and a regulated market related to the underlying asset. While BZX claimed it had entered into a comprehensive surveillance-sharing agreement with Gemini, the SEC found Gemini's bitcoin trading volume and liquidity to be insufficient and that a person who sought to manipulate the ETP could do so by trading on other exchanges, thus rendering the information sharing agreement irrelevant. ${ }^{139}$ Furthermore, because the Gemini auction price is used to determine the net asset value of the Gemini Trust, "which is publicly disseminated and which is the price used for creation and redemption transactions," low auction volumes make manipulation of Trust shares more likely. ${ }^{140} \mathrm{Be}$ cause the creation of one Trust share requires the Trust to purchase 1,000 bitcoin, the creation of a new Trust share could substantially increase the

135. SEC Release No. 34-83723, supra note 132, at 20.

136. The Intraday Indicative Value (IIV) of the Trust would be calculated and disseminated by the Sponsor, every 15 seconds during BZX's regular trading session, based on the most recent Gemini Auction price. The Net Asset Value (NAV) of the Trust would be calculated each business day, based on the clearing price of that day's 4:00p.m. Eastern Time (ET) Gemini Exchange bitcoin auction. See SEC Disapproval Order, supra note 28, at 4.

137. SEC Release No. 34-83723, supra note 132, at 21.

138. SEC Release No. 34-83723, supra note 132, at 21.

139. The SEC also found that the Gemini exchange did not constitute a "regulated" exchange. See SEC Release No. 34-83723, supra note 132, at 66.

140. SEC Release No. 34-83723, supra note 132, at 39. 
price of bitcoin, and by extension a Trust share, assuming it is purchased on the Gemini exchange. ${ }^{141}$

\section{G. Differences Between the CFTC and SEC When it Comes to New Product Approval}

One explanation for why the SEC is concerned about manipulation in the bitcoin spot market, while the CFTC is not, lies in statute. The Exchange Act requires exchanges - in their role as self-regulatory organizations - to file any proposed rule changes with the SEC, who then must make an affirmative finding that the proposed rule change is consistent with the Exchange Act, and the burden of demonstrating consistency with the Exchange Act lies with the exchange proposing the rule change. ${ }^{142}$ This contrasts with the self-certification process, which places the burden of proof on the CFTC if they wish to prevent an exchange from self-certifying a new derivatives product.

The Exchange Act also mandates that the rules of an exchange be designed to prevent "fraudulent and manipulative acts and practices." 143 However, neither the Exchange Act nor SEC regulations differentiate between fraud and manipulation in the spot (cash) market and the market for the product the exchange is seeking to list through the rule change proposal (e.g., the Winklevoss Bitcoin Trust). Therefore, the SEC has taken a more expansive view of fraud and manipulation compared to the CFTC, which is only focused on fraud and manipulation in the futures market.

The SEC's broader view makes sense in light of the fundamental differences between the two products. Manipulating a cash settled futures contract requires the underlying reference price be manipulated, which is why so much attention was placed on the bitcoin reference rate for the CME and CFE contracts. Shares of a bitcoin ETP would be priced upon transactions in the open market, but the net asset value of the Gemini Trust that would issue the shares is based upon the 4 PM Gemini auction. Because the creation (redemption) of an ETP share requires the purchase (sale) of 1,000 bitcoin, any kind of manipulation in the bitcoin spot market, regardless of where it occurs, could influence the value of the

141. The bitcoins don't have to be purchased from Gemini, but if authorized participants are forced to source bitcoin from other venues, the prices may not be aligned with the Gemini auction. SEC Release No. 34-83723, supra note 132, at 39.

142. 15 U.S.C. $\S 78 f(b)(5)$.

143. Id. 
ETP, which is why the SEC focused more broadly on characteristics of the bitcoin spot market. ${ }^{144}$

The SEC did identify problematic features of the Gemini exchange and auction that are applicable to CFE's bitcoin futures contract but were ignored by the CFTC in their review. Because the net asset value of the Trust is determined by the Gemini auction, the creation and redemption of new Trust shares results in the purchase, or sale, of significantly more $(1,000)$ bitcoin than typically trades on the Gemini 4 PM auction. Therefore, had the SEC approved the BZX rule change, the mere act of creating or redeeming Trust shares could have influenced the auction price and therefore the Trust's pricing. ${ }^{145}$ This should have been a red flag for the CFTC, which knew that the SEC was reviewing the BZX proposal when they reviewed the self-certifications. If the creation and redemption of Trust shares could influence the Gemini auction, it could also influence the settlement value of CFE's bitcoin futures contract. The CFTC was fully aware there could one day be a bitcoin ETP, yet there is no evidence they considered the impact an ETP could have on the ability to manipulate bitcoin futures.

Many market observers think a bitcoin exchange traded product is inevitable, and already there are indications that the SEC is softening its stance. SEC Commissioner Hester Peirce released a public dissent following the SEC's most recent disapproval of the BZX rule change, in which she criticized the majority's excessive focus on the bitcoin spot market. ${ }^{146}$ Peirce notes that the language of the Exchange Act states that "[t]he rules of the exchange" must be designed "to prevent fraudulent and manipulative acts and practices." 147 Commissioner Peirce believes this language requires a more narrow focus on the actual exchange rule(s) in question, in this case, BZX Rule 14.11(e)(4) which governs the listing and trading of commodity-based trust shares. ${ }^{148}$ Peirce believes that this rule, coupled with BZX's role as a self-regulatory organization, is

144. This problem largely applies to any kind of exchange-traded product that is based on an illiquid asset. See, e.g., Ian Foucher \& Kyle Gray, Exchange-Traded Funds: Evolution of Benefits, Vulnerabilities and Risks, BANK OF CAN. FIN. SYs. REV. 37, 42 (Dec. 2014) (discussing liquidity risk in the context of "Authorized Participants"); DEPOSITORY TRUST CLEARING Corp., The Next Crisis Will Be Different: Opportunities To Continue Enhancing Financial Stability 10 Years After Lehman's Insolvency, Industry White Paper 13 (Sept. 2018).

145. SEC Release No. 34-83723, supra note 132, at 39.

146. Hester M. Peirce, Commissioner, Sec. and Exch. Comm'n, Dissent of Commissioner Hester M. Peirce to Release No. 34-83723; File No. SR-BatsBZX-2016-30 (July 26, 2018), https://www.sec.gov/news/public-statement/peirce-dissent-34-83723\#_ftn3.

147. Id. (emphasis added by Peirce).

148. Сboe BZX Exchange, Inc., Rules of Cboe BZX Exchange, Inc., 238 (Updated last Oct. 18, 2018), $\quad$ https://www.batstrading.com/resources/regulation/rule_book/BATS_Exchange_Rulebook.pdf. 
sufficient to prevent fraud and manipulation in the Trust shares. Peirce states that the "Commission steps beyond this limited role when it focuses instead on the quality and characteristics of the markets underlying a product that an exchange seeks to list."149

Peirce's insistence that the SEC focus exclusively on the proposed product mirrors the approach taken by the CFTC. However, the Exchange Act language is more ambiguous than the CEA and CFTC regulations, therefore allowing for greater discretion in its interpretation by SEC commissioners. Specifically, the Exchange Act does not state where fraud and manipulation should be prevented. Such discretion leaves open the possibility for some form of virtual currency exchange traded product to enter the market in the near future, provided the SEC includes more commissioners who share Commissioner Peirce's views.

\section{BITCOIN FutURES INTRODUCE SySTEMIC RISK}

\section{A. Bitcoin Futures as Speculative Investments}

Neither the CFTC nor the SEC considered the economic purpose of bitcoin derivatives in their respective reviews. ${ }^{150}$ The CFTC acknowledged that even had it been considered, it would play no role in their decision-making. Speaking at the MRAC meeting, Amir Zaidi, the Director of the CFTC's Division of Market Oversight, noted that "[q]uestionable social utility and price valuations of a new asset class are not sufficient reasons for the CFTC to set regulatory policy."151

Although not required, CFE attempted to articulate the economic utility of bitcoin futures in their self-certification, stating that the contracts "could be used by a number of different groups for commercial purposes, including by bitcoin miners to hedge production costs, bitcoin merchant processors to hedge inventories, merchants that accept bitcoin to hedge bitcoin inventories, and holders of bitcoin that wish to hedge their bitcoin holdings." 152 While some within these groups may desire bitcoin futures for genuine hedging purposes, their numbers are far too small to warrant the development of a new futures contract. Furthermore, the public record shows scant evidence of commercial entities advocating

149. Peirce, supra note 146.

150. This is largely because the relevant statutes do not require them to. However, Section 6(b)(5) of the Exchange Act does require the rule of an exchange be designed to "protect investors and the public interest." This language is broad enough to allow the SEC to consider the economic utility of new products, but rarely do they do so. 15 U.S.C. $\S 78 f$.

151. Transcript of Market Risk Advisory Committee Meeting, supra note 123.

152. Product Certification Letter from Choe, supra note 74, at 4. 
for the creation of bitcoin derivatives products for risk management purposes.

Bitcoin's limitations as a payment method are well documented: it is too volatile, transactions take far longer to process than credit card networks, and transaction costs are high compared to traditional payment methods. ${ }^{153}$ Although exact data is difficult to ascertain, anecdotal evidence suggests that very few merchants accept bitcoin as payment, and for those that do, bitcoin constitutes a very small fraction of total sales volume.

It is clear that demand for bitcoin derivatives is coming not from merchants that transact in bitcoin, but from speculators that want bitcoin exposure without having to own actual bitcoin. ${ }^{154}$ In their proposed rule change to list and trade shares of the Winklevoss Bitcoin Trust, BZX acknowledged the obvious: "The Shares are designed for investors seeking a cost-effective and convenient means of gaining investment exposure to bitcoin similar to a direct investment in bitcoin." 155

Given that activity in the bitcoin spot market is primarily speculative, it follows that any kind of bitcoin derivative would appeal principally to speculators. Many scholars have equated speculating in financial markets to gambling, ${ }^{156}$ whose social ills have long been understood. ${ }^{157}$ Speculation in financial markets is made possible when two or more parties have different views about future economic events. Eric Posner and Glen Weyl argue that when parties act on this difference through financial speculation (gambling), it is welfare-reducing and contributes to systemic risk by increasing the overall level of risk in the financial system. ${ }^{158}$

153. See, Governor Philip Lowe, Address to the 2017 Australian Payment Summit Sydney, n.3 (Dec. 13, 2017), https://www.rba.gov.au/speeches/2017/sp-gov-2017-12-13.html\#r3 (discussing the drawbacks of cryptocurrencies, such as bitcoin, and why traditional banks are still likely to play an essential role in electronic payments).

154. There are many reasons why an investor may avoid the bitcoin spot market: it's unregulated, exchanges frequently get hacked, private keys may be lost. See Levine, supra note 13 (noting the reasons why investors seeking exposure to bitcoin may prefer cash-settled futures to actual bitcoin).

155. Sec. and Exch. Comm'n, Release No. 34-79183 at 44 (Oct. 28, 2016), https://www.sec.gov/rules/sro/batsbzx/2016/34-79183.pdf.

156. See, e.g., Eric A. Posner \& E. Glen Weyl, An FDA for Financial Innovation: Applying the Insurable Interest Doctrine to Twenty-First-Century Financial Markets, 107 Nw. U. L. REV. 1307 (2015) (insert parenthetical); Timothy E. Lynch, Gambling by Another Name; The Challenge of Purely Speculative Derivatives, 17 StAn. J. L., Bus., \& Fin. 67 (2012).

157. Geoffrey Clark, Betting on Lives: The Culture of Life Insurance in England, 1695-1775 (1999) (for a general critique of using life insurance contracts as a vehicle for gambling).

158. This argument is premised on the assumption that market participants are risk averse. See Posner \& Weyl, supra note 156, at 1309 ("[G]ambling may have some ancillary benefits in improving the information in market prices. However, it is overwhelmingly a negative-sum activity, which, in the aggregate, harms the people who engage in it, and which can also produce negative third-party effects by increasing systemic risk in the economy."). 
Taking these arguments as given, this section assesses the other ways in which bitcoin futures contracts contribute to systemic risk, defined as the risk that a disruption in the financial system could impair all, or parts of, the financial system and potentially have negative consequences for the real economy. ${ }^{159}$

While there are a number of factors that contribute to the accumulation, materialization, and transmission of systemic risk, there is no universally accepted accounting of all these factors. ${ }^{160}$ Rather than review the academic literature on systemic risk factors, the analysis below focuses solely on the factors that are most relevant to bitcoin futures.

\section{B. New Interconnections and Risk Concentrations}

Interconnections between various firms and markets in the financial system may allow systemic risk to accumulate and can facilitate the transmission of economic shocks throughout the system. ${ }^{161}$ Interconnections between firms can take the form of "asset interconnectedness" and/or "liability interconnectedness." 162 Asset interconnectedness occurs when one or more financial institutions have direct credit exposure to a failed financial institution. Liability interconnectedness refers to the situation where a financial institution provides funding to other institutions and the withdrawal of that funding leads to a cascade of firm failures. Interconnections can also form between various markets and asset classes. For instance, derivatives can connect the regulated sector with the unregulated sector if the underlying asset is unregulated.

159. There is no universally accepted definition of systemic risk, so I have borrowed heavily from the definition supplied by the International Monetary Fund, Bank for International Settlements, and the Financial Stability Board. InT'L Monetary Fund ET AL., GuIDANCE TO AsSESS THE SySTEMIC IMPORTANCE OF FinANCIAL InSTITUTIONS, MARKETS AND InSTRUMENTS: InITIAL CONSIDERATIONS (Report to the G-20 Finance Ministers and Central Bank Governors Oct. 28 2009), https://www.imf.org/external/np/g20/pdf/100109.pdf.

160. See, e.g., Kathryn Judge, Fragmentation Nodes: A Study In Financial Innovation, Complexity, and Systemic Risk, 64 Stan. L. Rev. 657 (2012); Manuel A. Utset, Complex Financial Institutions and Systemic Risk, 45 Ga. L. Rev. 779 (2011); Steven L. Schwarcz, Systemic Risk. Duke Law School Legal Studies Paper No. 163; GEORGETOwn LAw Journal, Vol. 97, No. 1, (2008); Viral V. Acharya, et al., Measuring Systemic Risk. AFA 2011 Denver Meetings Paper 1 (2010); Olivier de Bandt \& Philipp Hartmann, Systemic Risk: A Survey, ECB Working Paper No. 35 (2000); Monica Billio, et al., Econometric measures of connectedness and systemic risk in the finance and insurance sectors, 104 J. of Fin. Econ. 535 (2012).

161. See, e.g., Judge, supra note 160 (discussing the increased systemic risk caused by the securitization of home loans in the context of the 2008 financial crisis); Stefano Battiston et al. The Price of Complexity in Financial Networks, 113(36) PNAS 10031 (Sept. 6, 2016), http://www.pnas.org/content/113/36/10031.

162. Hal S. Scott, Interconnectedness and Contagion, CommitTEe ON CAP. MKT. ReG. (Nov. 20, 2012), https://www.capmktsreg.org/wp-content/uploads/2014/11/2012.11.20_Interconnectedness_and_Contagion.pdf. 
The introduction of bitcoin futures created new connections between firms and market sectors. Most significantly, it pierced the barrier that had previously separated the unregulated bitcoin spot market from the regulated financial system. ${ }^{163}$ Not only did bitcoin futures expose two regulated futures exchanges to the risks associated with a new asset class, but they exposed Futures Commission Merchants ("FCMs") to these risks as well. FCMs solicit orders to buy and sell futures contracts from retail and institutional investors; margin and guarantee customer trades; and in some instances, extend credit to customers. The nine largest $\mathrm{FCMs}^{164}$ are owned by firms classified as global systemically important banks ("GSIBs") by the Financial Stability Board. ${ }^{165}$ Accordingly, bitcoin futures contracts transformed what was previously an unregulated asset class dominated by retail investors, into a lengthy intermediation chain that includes some of the world's largest exchanges, clearinghouses, and toobig-to-fail financial institutions.

Bitcoin futures also brought central counterparty clearinghouses ("CCPs" or "clearinghouses") into the bitcoin intermediation chain. A CCP interposes itself between counterparties to contracts traded in one or more financial markets - becoming the buyer to every seller and the seller to every buyer - thereby ensuring the performance of the contracts. ${ }^{166}$ The use of central clearing expanded substantially after the financial crisis when G20 leaders agreed that "all standardized OTC derivative contracts should be traded on exchanges or electronic trading platforms, where appropriate, and cleared through central counterparties by end2012 at the latest." 167 While the growth in central clearing has removed much of the counterparty credit risk associated with bilateral trading exposures that proved so detrimental in 2008 , it has led to new concerns

163. There had been other bitcoin derivatives prior to bitcoin futures but these were less liquid, lightly traded, and generally accessible to qualified investors only. See LabCFTC, supra note 4 (providing an overview of virtual currencies).

164. Based on customer funds held in segregation. 2017 Top FMCs, AiSourCE (Feb. 28, 2018), https://www.managedfuturesinvesting.com/2017-top-fcms/.

165. Fin. Stability BOARD, 2017 List OF Global SystemiCAlly IMPORTANT BANKS (GSIBs), (Nov. 21, 2017), http://www.fsb.org/wp-content/uploads/P211117-1.pdf.

166. See Bank for Int'L Settlements \& InT'L Org. Of Sec. Comm'N, Principles for FinANCIAL MARKET INFRASTRUCTURES 9 (2012), https://www.bis.org/cpmi/publ/d101a.pdf (noting the definition of central counterparty).

167. G20 Leaders Statement: The Pittsburgh Summit, provided by G20 Research Group (Sept. 24-35, 2009), http://www.g20.utoronto.ca/2009/2009communique0925.html. 
that too much risk is concentrated at CCPs,${ }^{168}$ making them a potential source of systemic risk. ${ }^{169}$

Not only do CCPs concentrate risk by combining the exposures of all clearing members on their own balance sheet, but they also form new connections due to the fact that other financial institutions may have relationships with CCPs as clearing members, custodians, settlement banks, credit and liquidity providers, and investment counterparties. ${ }^{170}$ The fear is that problems at one or more CCPs could be the spark that allows systemic risk to travel throughout, and infect, the rest of the financial system. ${ }^{171}$

This fear is not unfounded. In August 2018, the Financial Stability Board, the Committee on Payments and Market Infrastructures, the International Organization of Securities Commissions, and the Basel Committee on Banking Supervision, released a report that assessed central clearing interdependencies utilizing data collected from twenty-six CCPs across fifteen jurisdictions. ${ }^{172}$ The report found that the two largest CCPs accounted for nearly $40 \%$ of the prefunded financial resources, in the form of initial margin and default fund contributions, provided to all CCPs. ${ }^{173}$ The report also found that eleven clearing members are connected to between sixteen and twenty-five CCPs. As the report notes: "This indicates that the default of a CCP's clearing member could result in defaults of the same entity or affiliates in up to 24 other CCPs."

CME's bitcoin futures contract is cleared through CME's own clearing entity ("CME ClearPort") while CFE's contract is cleared through the Options Clearing Corporation ("OCC"). ${ }^{174}$ Given bitcoin's novelty and unique risk characteristics, several members of these CCPsmany of whom are FCMs - expressed concern over the launch of bitcoin

168. See, Jeanna Smialek, Gary Cohn Calls Clearinghouses a 'New Systemic Problem', BLOOMBERG (Oct. 15, 2017), https://www.bloomberg.com/news/articles/2017-10-15/whitehouse-s-cohn-calls-clearinghouses-a-new-systemic-problem ("As 'we get less transparency, we get less liquid assets in the clearinghouse, it does start to resonate to me to be a new systemic problem in the system,' Cohn, director of the White House's National Economic Council, said at a banking conference in Washington.").

169. To better understand the risks associated with CCPs, see Colleen Baker, Clearinghouses for Over-The-Counter Derivatives 32-35 (Volcker Alliance, Working Paper Nov. 2016).

170. Id. at 7.

171. Also called contagion.

172. Basel Committee on Banking Supervision et al., Analysis of Central CleARING InTERDEPENDENCIES (Aug. 9, 2018), https://www.bis.org/cpmi/publ/d181.pdf.

173. The report does not mention any of the CCPs by name.

174. CFE's parent entity, Cboe Global Markets Inc., is one of three shareholders in the OCC. The other two are Intercontinental Exchange Inc.'s New York Stock Exchange and Nasdaq. See Gunjan Banerji, A Messy Battle Brews in the Options Market, Wall St. J. (Aug. 22, 2018), https://www.wsj.com/articles/a-messy-battle-brews-in-the-options-market1534939201? redirect=amp\#click=https://t.co/11XXjheHPv. 
futures. In fact, upon initial launch, several FCMs, including those controlled by JPMorgan, Bank of America, and Citigroup, refused to offer their customers access to bitcoin futures due to concerns around client suitability and overall volatility in the bitcoin spot market. ${ }^{175}$

Clearinghouse members also questioned the appropriateness of utilizing the self-certification process to list novel products like bitcoin futures. Shortly before the launch of CFE's contract, the Futures Industry Association ("FIA"), a global trade organization for the futures, options, and centrally cleared derivatives markets, sent an open letter to CFTC Chairman Christopher Giancarlo, arguing that the self-certification of bitcoin futures did not allow for adequate dialogue between regulators, exchanges, clearinghouses and clearing members. ${ }^{176}$ The FIA's main concern is that clearing members who do not trade bitcoin futures may be forced to cover any losses - through guarantee fund contributions and assessment obligations - should a clearing member who does trade bitcoin futures default. The FIA believes "a public discussion should have been had on whether a separate guarantee fund for this product was appropriate or whether exchanges put additional capital in front of the clearing member guarantee fund." 177

Under CFTC Regulation 40.6, derivatives clearing organizations ("DCOs") are required to submit any new rule changes or rule amendments to the CFTC, which then has ten days to review the submission before the rule or amendment takes effect. ${ }^{178}$ Furthermore, because CME has been designated as a systemically important DCO ("SIDCO") by the Financial Stability Oversight Council, they must provide the CFTC with sixty days' advanced notice of any proposed changes to its rules, procedures, or operations that could materially affect the nature or level of risk presented by the SIDCO. ${ }^{179}$ Despite bitcoin's novelty, CME and the OCC proposed using their existing margin methodology for bitcoin futures. With no change to their margin methodology or to their existing risk management practices, there was no need to file a rule change. ${ }^{180}$

175. See Alexander Osipovich et al., Wall Street Banks Hit Pause Button on Bitcoin, WALL St J. (Dec. 7, 2017), https://www.wsj.com/articles/wall-street-banks-hit-pause-button-onbitcoin-1512674703.

176. Open letter from Walt Lukken, Chief Exec. Officer, Futures Industry Association to Christopher Giancarlo, Chairman, Commodity Futures Trading Commission (Dec. 6 2017), https://fia.org/articles/open-letter-cftc-chairman-giancarlo-regarding-listing-cryptocurrencyderivatives.

177. Id.

178. 17 C.F.R. $\S 40.6$.

179. 17 C.F.R. $\S 40.10$.

180. The CFTC agreed with this assessment. From the MRAC meeting, "We had discussions with them; we checked on that; and we agreed that there was no rule change that was required in terms of operations and procedures." See TRANSCRIPT OF MARKET RISK ADVISORY COMmittee MeEting, supra note 123, at 72. 
The clearinghouses' basic argument for not filing a rule change was that they have a long history of risk managing and margining volatile financial products, and that bitcoin futures did not present any unique risks they had not seen before. The CFTC agreed with this assessment despite clear evidence that bitcoin does present novel risks and a 2013 censure of the OCC's risk management practices by the SEC. ${ }^{181}$ The CFTC even acknowledged that product novelty does not factor into its risk assessments. Speaking at the MRAC meeting in January 2018, Brian Bussey, the CFTC's director of the Division of Clearing and Risk ("DCR"), stated that DCR does not consider the "clearing of a new product standing alone as a change that could materially affect the nature or level of risks presented by a SIDCO." 182

The key challenge for both clearinghouses leading up to contract launch was establishing an appropriate margin methodology. CFTC regulation 39.13 requires initial margin to meet a $99 \%$ confidence level "based on data from an appropriate historic time period." 183 According to the CFTC, the initial margin requirements established by CME and the OCC for bitcoin futures approached the "100 percent confidence level based on available data that we have going back five years in Bloomberg." "184 Considering that bitcoin was less than ten years old at the time, and did not surpass the $\$ 1,000$ price level until February 2017, five years may not have been "an appropriate historic time period." 185

Relying on recent data for risk models has a well-documented and problematic history. During the financial crisis, value-at-risk ("VaR") models for measuring investment-portfolio risk grossly underestimated risk in part by overly relying on data from recent periods of market tranquility. The consequences of recency bias in risk models revealed themselves again in February 2018. On February 5, a 4.1\% drop in the S\&P 500 led the Cboe volatility index (the "VIX") to spike after it had been at near record lows for several years prior. ${ }^{186}$ The spike in volatility led exchange traded products ("ETPs") that bet against the VIX to lose more

181. See Jacob Bunge, SEC Criticizes Management at Options Clearing Corp., WaLL ST. J. (Oct. 22, 2013), https://www.wsj.com/articles/sec-criticizes-management-at-options-clearing-corp-1382414459?mod=article_inline.

182. Busey stated that DCR has reviewed new products pursuant to Regulation 40.10 in the past; but when it has done so, it has been in combination with a new margin methodology or changes to an existing margin methodology, or other changes to risk management involved with the introduction of the new product. See TransCript of MARKET Risk Advisory Committee Meeting, supra note 123, at 72.

183. 17 C.F.R. $\S 39.13(\mathrm{~g})(2)(\mathrm{iii})$.

184. TransCript OF MARKet Risk Advisory Committee MeEting supra note 123, at 82.

185. 17 C.F.R. $\S 39.13(\mathrm{~g})(2)($ iii).

186. INVESTING.COM, https://www.investing.com/indices/us-spx-500-historical-data (last visited Jan. 29, 2019) (providing historical data on the S\&P 500). 
than $80 \%$ of their value and several of these ETPs were forced to shut down. ${ }^{187}$ Trading losses associated with VIX products also led to a jump in margin breaches at the OCC. The OCC reported that the average size of traders' margin breaches jumped from \$26,355 at the end of 2017 to $\$ 61.4$ million in the first quarter of $2018,{ }^{188}$ prompting the CFTC and SEC to open an investigation into the OCC's margining practices.

It did not take long for bitcoin's limited price history to force changes in how bitcoin futures were margined. In conversations with the CFTC prior to self-certification, CME stated they had established a range of $27 \%$ to "the mid $30 \mathrm{~s}$ " for initial margin on bitcoin futures. ${ }^{189}$ The CFTC backtested the 27\% figure and agreed that it met the $99 \%$ confidence level requirement, but significant upside volatility in the bitcoin spot market in the fall of 2018 led CME to settle on a 35\% initial margin requirement by the time they submitted their self-certification on December $1,2017 .^{190}$ Bitcoin's volatility reached record highs in December 2017 , with the price rising from $\$ 10,859$ on December 1 to $\$ 15,036$ on December 10 (the date CFE launched their futures contract). ${ }^{191}$ The jump in volatility compelled $\mathrm{CME}$ to increase initial margin requirements yet again, to $47 \%$, on December 12 , just five days prior to the launch of their contract. ${ }^{192}$ Despite the ratcheting up of CME's initial margin requirement in response to increased volatility in the weeks leading up the launch of bitcoin futures, the CFTC maintains that the originally proposed $27 \%$ initial margin requirement "would have been within the confidence requirements of our regulations.", 193

Bitcoin clearly has unique risk characteristics that, when coupled with a limited price history, makes managing related risk exposures challenging. While there has yet to be a known margin breach associated with a bitcoin futures position, there is no guarantee there never will be. If there is, financial institutions that previously thought they had no

187. See Asjiylyn Loder \& Dave Michaels, Market Volatility Strikes Exchanges-Traded Products, Alarming Investors and Regulators, WALL ST. J. (Feb. 12, 2018), https://www.wsj.com/articles/market-volatility-strikes-exchange-traded-products-alarminginvestors-and-regulators-1518440400? $\mathrm{mod}=$ article_inline.

188. Dave Michaels \& Gunjan Barerji, Regulators Probe Options Market's Major Clearinghouse, WALL ST. J. (Aug. 2, 2018), https://www.wsj.com/articles/regulators-probe-majorclearinghouse-of-options-market-1533202200?mod=article_inline.

189. Transcript of Market Risk Advisory Committee Meeting, supra note 123, at 120.

190. Id.

191. CoInMARKetCAP, supra note 15.

192. See Annie Massa, Higher Margins Set for CME's Soon-to-Launch Bitcoin Futures, BLOOMBERG (Dec. 12, 2017), https://www.bloomberg.com/news/articles/2017-12-12/highermargins-set-for-cme-s-soon-to-launch-bitcoin-futures.

193. Transcript of Market Risk Advisory Committee Meeting, supra note 123, at 121. 
exposure to bitcoin may find that through bitcoin futures, they became enmeshed in a volatile, and largely unregulated, global asset class.

\section{Complexity}

The role of complex financial products in the 2008 financial crisis is well-documented. ${ }^{194}$ Complexity allows systemic risk to accumulate in the financial system unnoticed by market participants and regulators. ${ }^{195}$ In the run-up to 2008, many "sophisticated" investors purchased mortgage-backed securities and other securities tied to the housing market whose risk characteristics they thought they understood. ${ }^{196}$ When housing prices declined, many of these securities defaulted or lost much of their value, and their investors were threatened with insolvency. In an effort to meet demands for more collateral, many of these investors were forced to liquidate additional assets, which led to further declines in asset prices (known as the "fire-sale" dynamic).

Bitcoin futures contracts are also complex. While futures contracts have existed for over 100 years and are a fairly straightforward product, bitcoin itself is a new asset class that is not widely understood. ${ }^{197}$ A 2018 survey of over 5,000 American adults found that $60 \%$ of respondents have heard of bitcoin while only $5 \%$ own bitcoin. ${ }^{198}$ While this gap is likely due to a number of factors, a lack of understanding of how bitcoin works is certainly a contributor.

Adding to the confusion around bitcoin is the concept known as a "hard fork." ${ }^{199}$ A hard fork is a permanent divergence from the previous version of the bitcoin blockchain; nodes running previous versions of the blockchain protocol will no longer be accepted by the newest version.

194. See, e.g., Steven L. Schwarcz, Regulating Complexity in Financial Markets, 87 Wash. U. L. Rev. 211, 241-42 (2009); see Dan Awrey, Complexity, Innovation, And The Regulation of Modern Financial Markets, 2 HARV. Bus. L. ReV. 235 (2012).

195. See, e.g., Heather Hughes, Financial Product Complexity, Moral Hazard, and the Private Law, 20 StAn. J.L. Bus. \& Fin. 179 (2015); Judge, supra note 160; Battiston et al., supra note 161 .

196. This understanding was facilitated by the credit ratings agencies who supplied favorable ratings to many of these securities. See e.g., Marc Allen Eisner, Before the Third Act: Crony Capitalism and the Origins of the Financial Crisis, 11 Geo. J. of L. \& TeCH. 391, 409 (2013) (discussing the role credit rating agencies played in contributing to the crisis).

197. It would be like if mortgage-backed securities were complex because no one understood what a mortgage was.

198. Survey Monkey and Global Blockchain Business Council Study American Attitudes on Bitcoin, COINWIRE (Jan. 26, 2018), https://www.coinwire.com/survey-monkey-andglobal-blockchain-business-council-study-american-attitudes-on-bitcoin.

199. See Understanding Hard Forks in Cryptocurrency, CRYPTOCuRRENCY FACTS https://cryptocurrencyfacts.com/understanding-hard-forks-cryptocurrency/ (last visited Jan. 29, 2019). 
This leads to a fork in the blockchain (thus the term "hard-fork"): one path follows the new, upgraded blockchain, and the other continues along the old path. The bitcoin blockchain has undergone several hard forks in its short history, ${ }^{200}$ typically due to disagreements amongst bitcoin developers over transaction processing speed. The most notable hard fork occurred in August 2017, when Bitcoin Cash was created. ${ }^{201}$ Should another hard fork of the main bitcoin protocol occur in the future, there will be uncertainty as to which asset is underlying bitcoin futures contracts.

$\mathrm{CME}$ and CFE describe their hard fork policy in their self-certifications. CFE states that if a hard fork were to occur, the final settlement value of their bitcoin futures contract will be based on the form of bitcoin traded on the Gemini Exchange. ${ }^{202}$ They note, "Gemini will elect to support the Bitcoin Network that has the greatest cumulative computational difficulty for the forty-eight hour period following a given hard fork."203 CME's hard fork policy is more vague: "the exchange shall have the discretion to take action in consultation with market participants to align Bitcoin Futures position holder exposures with cash market exposures as appropriate." 204

The potential for a hard fork adds to the complexity of bitcoin futures contracts. Most investors in bitcoin futures are probably unaware of what would happen to their contract in the event of a hard fork, and if another hard fork were to occur, it could be a triggering event that leads to mass selling in the bitcoin spot market as well as the futures market. $^{205}$

\section{Market Size}

Size is a key indicator of a market's systemic importance ${ }^{206}$ - the bigger the market, the greater the economic cost should that market fail. Presently, the virtual currency market is not big enough to pose a

200. Nathan Reiff, A History of Bitcoin Hard Forks, Investopedia (Apr. 25, 2018), https://www.investopedia.com/tech/history-bitcoin-hard-forks/.

201. Bitcoin cash itself underwent a hard fork on November 15, 2018, leading to the creation of Bitcoin SV. See, Nathan Reif, All About the Bitcoin Cash Hard Fork, InVESTOPEDIA (Nov. 15, 2018), https://www.investopedia.com/news/all-about-bitcoin-cash-hard-fork/.

202. Product Certification Letter from Cboe, supra note 74, at 5.

203. Product Certification Letter from Cboe, supra note 74, at 5.

204. Bowen, supra note 74, at 11.

205. Although the contact specifications do indicate there is potential for a hard fork, you could argue that the concept is too complex to be appropriately explained to investors. See e.g., Henry Hu, Too Complex to Depict? Innovation, "Pre Information," and the SEC Disclosure Paradigm, 90 TEX. L. REV. 1601 (2012).

206. The IMF also lists substitutability and interconnectedness as the key criteria for identifying the systemic importance of markets and institutions. See InT'L MONETARY Fund ET AL., supra note 158 . 
systemic risk. In a March 2018 letter to G20 finance ministers and central bank governors, the Financial Stability Board acknowledged that "crypto-assets do not pose risks to global financial stability at this time." 207 The letter notes that the combined global market value of all crypto-assets was less than 1\% of global GDP; "[i]n comparison, just prior to the global financial crisis, the notional value of credit default swaps was $100 \%$ of global GDP." 208

While the crypto-asset market may currently be too small to threaten financial stability, financial markets are not static. The virtual currency market has exhibited extraordinary growth and volatility in a short period of time. As of December 1, 2018, bitcoin's market capitalization was approximately $\$ 73$ billion. $^{209}$ Although this is $\$ 156$ billion less than what it was at the beginning of $2018,{ }^{210}$ it still stands in stark contrast to bitcoin's market capitalization on January 1, 2017, of approximately $\$ 16$ billion. $^{211}$ Bitcoin futures contracts and other virtual currency investment products provide an opportunity for this market to grow further by bringing in new investor classes. Should the SEC ever approve a bitcoin exchange traded product, the virtual currency market would grow even larger.

The evolution of the mortgage-backed securities market may serve as a useful analogy when considering the potential for the virtual currency market to reach systemic proportions. The first mortgagebacked security ("MBS") was issued in 1968; it was privately issued but guaranteed by the Government National Mortgage Association ("Ginnie Mae"). ${ }^{212}$ In 1971, the Federal Home Loan Mortgage Corporation ("Freddie Mac") issued its first MBS and ten years later, the Federal

207. Fin. Stability Board, To G20 Finance Ministers and Central Bank Governors (Mar. 13, 20182918), https://cdn.crowdfundinsider.com/wp-content/uploads/2018/03/Financial-Stability-Board-Letter-to-G20-March-2018.pdf.

208. The FSB's sentiments were echoed by Federal Reserve Chairman, Jerome Powell, on July 18th, 2018, when he indicated during a House Financial Services Committee that the virtual currency market is not big enough to threaten financial stability. See Olga Kharif, Powell Says Cryptocurrencies Aren't Big Enough to Pose a Threat, BloOMBERG QuINT (July 18, 2018), https://www.bloombergquint.com/business/2018/07/18/powell-says-cryptocurrencies-aren-t-big-enough-to-pose-a-threat\#gs.QB8Df4A.

209. COINMARKETCAP, supra note 15.

210. For a summary of bitcoin's precipitous decline in 2018, see Tracy Alloway, A Year after the Crypto Bubble Burst, Will Bitcoin Ever Recover, BloOMBERG BUSINESSWEEK (Dec. 13, 2018), https://www.bloomberg.com/news/features/2018-12-13/where-does-bitcoin-gofrom-here?srnd=businessweek-v2

211. COINMARKETCAP, supra note 15.

212. See John J. McConnell \& Stephen A. Buser, The Origins and Evolution of the Market for Mortgage-Backed Securities, 3:1 ANN. REV. FIN. ECON. 173, 174 (2011), https://www.krannert.purdue.edu/faculty/mcconnell/publications/The-Origins-and-Evolution-of-the-Market.pdf. 
National Mortgage Association ("Fannie Mae") issued its first MBS. ${ }^{213}$ These initial issuances were simple pass-through securities, whereby investors would receive a proportional share of the monthly principal and interest payments from the underlying loans. It wasn't until 1983 that the first multiclass MBS, or Collateralized Mortgage Obligation ("CMO"), was issued by Freddie Mac. ${ }^{214}$ The MBS market grew gradually over the next decade, to the point where in 1996, total MBS issuances were approximately $\$ 550$ billion. ${ }^{215}$ But then, the market began to grow exponentially, topping over $\$ 1.2$ trillion in new issuance in 1998 and hitting a peak of $\$ 3.5$ trillion in new issuance in 2003 . $^{216}$

The growth in MBS paralleled, and contributed to, a growth in home prices that proved unsustainable. When the housing market collapsed beginning in 2006, it ultimately led to the near collapse of the financial system and a severe recession. The drop-in home prices revealed previously unknown connections between firms and sectors within the financial system. Many of these connections were formed by the purchase, sale, and repackaging of MBS.

It took decades for the MBS market to evolve to the point where it threatened financial stability. What began as a relatively straightforward product that was issued and guaranteed by government agencies or government-sponsored enterprises ("GSEs"), slowly morphed into a product with multiple, complex variations that involved GSEs, rating agencies, Wall Street firms, non-bank mortgage lenders, mortgage brokers and a diverse pool of investors that spanned the globe.

Ten years after bitcoin's launch, the virtual currency market has evolved in ways that even bitcoin's earliest and most ardent supporters would have had a hard time imagining. What will the market look like ten years from now? Of course, this question cannot be answered with any certainty, just as the future of the MBS market could not have been predicted with any certainty in the 1970s or 1980s. There are critical differences between the two markets that challenge an exact comparison. Most notably, the growth in the MBS market was encouraged and nurtured by the government, which viewed MBS as a tool to promote home ownership. ${ }^{217}$ Virtual currency lacks such government support, and at

213. Id. at 177 .

214. CMOs divided the issuance into tranches, with the first tranche receiving first rights to all principal payments (plus appropriate interest) from the underlying loans. Id.

215. US Mortgage-Related Issuance and Outstanding, SIFMA (Nov. 5, 2018), https://www.sifma.org/resources/research/us-mortgage-related-issuance-and-outstanding/.

216. Id.

217. See, e.g., Richard K. Green \& Susan M. Wachter., The American Mortgage in Historical and International Context, 14 J. OF ECON. PERS. 93, 94-100 (2005); N. Eric Weiss \& Katie Jones, Cong. Res. Serv., R42995, An Overview of the Housing Finance System in the United States, 7-12 (2017); Peter Wallison, Hidden in Plain Sight 100-237 (reprint ed. 2016); 
present, serves no useful social function, except in limited circumstances. ${ }^{218}$ Still, the virtual currency market will likely continue to grow - its exact pace unknown - aided in part by the creation of derivative products that will allow a greater number of investors to gain exposure to the asset class. This growth, when combined with the new connections that accompany it, will increase the systemic importance of the virtual currency market.

\section{E. Procyclical Regulation}

Procyclical regulatory policies and political economy are typically excluded from academic analysis around systemic risk factors. ${ }^{219}$ While their exact relationship to systemic risk is difficult to quantify, the historical record demonstrates that periods of financial boom preceding a crisis are typically accompanied by government policies that amplify credit booms, facilitate the growth of new financial product innovations, weaken existing regulations, and allow for regulatory forbearance. ${ }^{220}$ In essence, procyclical regulatory policies can create the conditions under which systemic risk is allowed to grow.

Bitcoin futures contracts were introduced in the midst of the longest bull market in U.S. history ${ }^{221}$ and at a time when U.S. financial regulatory agencies were pursuing deregulatory policies in line with the stated goals of President Trump. In May 2018, the President signed the Economic Growth, Regulatory Relief, and Consumer Protection Act into law. 222 Also in May 2018, U.S. regulators released a proposal to

Waltraud Schelkle, A Crisis of What? Mortgage Credit Markets and the Social Policy of Promoting Homeownership in the United States and Europe, 40(1) POL. \& SoC'y 59, 63-64 (2012); Michael Collins, Pursuing the American Dream: Homeownership and the Role of Federal Housing Policy, prepared at the request of the Millennial Housing Commission, 1324 (2002); Eisner, supra note 195.

218. Citizens in countries that suffer from hyperinflation, like Venezuela, have resorted to using virtual currency as a medium of exchange. See Christine Armario, Venezuelans Seeing Bitcoin Bseeing bitcoin oom as Survival, not Speculation, AP (Dec. 13, 2017), https://apnews.com/f7ccc4ea283746f28b261cabeaf8f0c5.

219. Charles Pouncy did recognize that political realities play a role in financial innovation. See Charles R.P. Pouncy, Contemporary Financial Innovation: Orthodoxy and Alternatives, 51 S.M.U. L. REV. 505 (1998).

220. See, e.g., Jihad Dagher, Regulatory Cycles: Revisiting the Political Economy of Financial Crises 3 (IMF, Working Paper No. 18/8, 2018).

221. The record was reached on August 22, 2018. See Gretchen Frazee, What the Longest Bull Market in History Means for the Economy and YourYiur Investments, PBS NEwsHouR (Aug. 22, 2018), https://www.pbs.org/newshour/economy/making-sense/what-the-longestbull-market-in-history-means-for-the-economy-and-your-investments.

222. The law is designed to provide regulatory relief to regional and community banks and does so by, amongst other elements: easing rules for mortgage lending by small banks, exempting banks with less than $\$ 10$ billion in assets from the Volcker Rule, and raising the asset 
"simplify and tailor compliance requirements" relating to the Volcker rule. ${ }^{23}$ The Volcker Rule was enacted as part of the Dodd-Frank Wall Street Reform and Consumer Protection Act of 2010 and it prohibits banks from trading for their own account or investing in, or sponsoring, hedge funds and private equity funds.

Viewed in isolation, these changes may have little impact on systemic risk. But, when observed through a broader historical lens, these changes fit a clear pattern of dialing-back financial regulation during periods of financial boom. A more permissive regulatory environment also facilitates the development of new financial products with unique risk characteristics. It is no coincidence that bitcoin futures were introduced eight years into a record bull market run. ${ }^{224}$ In addition to technological developments, bitcoin futures were made possible by investors' appetite for higher yielding assets - since the bull market has pushed the prices up for other financial assets - and a relaxed regulatory environment. Unfortunately, history indicates these factors often foretell of a coming financial crisis. ${ }^{225}$

\section{CONCLUSION}

This Article has contested the CFTC's claim that they had no grounds for halting the self-certification of bitcoin futures contracts. There were several red flags that should have been identified during the CFTC's "heightened review" of the contracts, all of which call into question the compliance with CFTC Core Principle 3: "[t]he board of trade shall list on the contract market only contracts that are not readily susceptible to manipulation." 226

In reviewing the contracts, the CFTC focused exclusively on the potential for contract manipulation and ignored underlying dynamics in

threshold (often referred to as the "SIFI" threshold) at which banks are subject to heightened supervision from $\$ 50$ billion to $\$ 250$ billion. See Economic Growth, Regulatory Relief, and Consumer Protection Act, Pub. L. No. 115-174 (2018), https://www.congress.gov/bill/115thcongress/senate-bill/2155.

223. Press Release, Fed. Res. Board, Federal Reserve Board Asks for Comment on Proposed Rule to Simplify and Tailor Compliance Requirements Relating to the "Volcker Rule" (May 30, 2018), https://www.federalreserve.gov/newsevents/pressreleases/bcreg20180530a.htm.

224. It is hard to imagine bitcoin futures contracts being rolled out in 2010 or 2011, when the financial crisis was still fresh in everybody's mind.

225. This echoes Hyman Minsky's financial instability hypothesis: "over a protracted period of good times, capitalist economies tend to move from a financial structure dominated by hedge finance units to a structure in which there is large weight to units engaged in speculative and Ponzi finance." See Hyman P. Minsky, Financial Instability Hypothesis 9 (Levy Econ. Inst. of Bard College, Working Paper No. 74, 1992).

226. 7 U.S.C. $\S 7(d)(3)$ 
the bitcoin spot market. Had they broadened their review to include the spot market, they would have identified a market ripe with fraud and manipulation, and perhaps recognized that it is naïve to think a futures contract based on an asset that is prone to manipulation can itself be resistant to manipulation.

The CFTC also ignored the systemic risk implications of allowing bitcoin futures to come to market. Prior to bitcoin futures, virtual currency was largely owned and traded outside the regulated financial sector, and the risks it posed to the rest of the financial system were minimal. The launch of bitcoin futures enmeshed systemically important financial institutions, including broker-dealers, central clearinghouses, and futures exchanges, in a volatile and little understood asset class.

By not halting the self-certifications, the CFTC placed the regulatory imprimatur on an asset class that, at the time, was in the midst of a speculative frenzy and whose true value remains questionable. In so doing, the CFTC contributed to a rapid integration of virtual currency with mainstream financial markets and institutions. In August 2018, Intercontinental Exchange announced that it is forming a new company called Bakkt, whose aim is to clear the way for major money managers to offer bitcoin mutual funds, pension funds, and ETFs as regulated investments. ${ }^{227}$ In October 2018, Fidelity also announced the launch of a virtual currency company to provide enterprise-grade custody solutions, a virtual currency trading execution platform and institutional advising services. ${ }^{228}$ While these initiatives may have happened regardless, the introduction of bitcoin futures almost certainly played a role in accelerating their development.

The CFTC has defended their actions by noting that Congress promulgated the self-certification process and that unless it is changed, "the staff of the CFTC must work responsibly within the self-certification structure." 229 Such protestations ignore the significant discretion the CFTC maintains when approving new products, as evidenced by the fact that the CFTC "held rigorous discussions with CME over the course of

227. Shawn Tully, The NYSE's Owner Wants to Bring Bitcoin to Your 401(k). Are Crypto Credit Cards Next?, ForTune (Aug. 3, 2018), http://fortune.com/longform/nyse-ownerbitcoin-exchange-startup/.

228. Michael Del Castillo, Fidelity Launches Institutional Platform for Bitcoin and Ethereum, FORBES (Oct. 15, 2018), https://www.forbes.com/sites/michaeldelcastillo/2018/10/15/fidelity-launches-institutional-platform-for-bitcoin-andethereum/\#7378a86c93c4.

229. COMMOdity Futures Trading COMM'N, supra note 62, at 2. 
six weeks" 230 and "CFE over the course of four months."231 According to the CFTC, these discussions resulted in "significant enhancements to contract design and settlement" at "the request of Commission staff." 232 The bottom line is that the CFTC could have halted the self-certifications had they wanted to.

The experience with bitcoin futures demonstrates the inherent weaknesses of the self-certification process in launching novel and complex financial products. Self-certification allows exchanges-who have a financial incentive to list new products, regardless of how risky they may be- to quickly list complex commodity derivatives with no public or market input, and minimal regulatory review. ${ }^{233}$

Several scholars have proposed reforms to the new product approval process. ${ }^{234}$ Saule Omarova advocates for a product approval process akin to what currently exists in the pharmaceutical industry in the U.S. ${ }^{235}$ The purpose of such a system is to ensure that "financial innovation and the creation of complex financial instruments actually advance productive economic enterprise and offer real public benefits." 236 Omarova's process consists of a three-prong test that financial institutions seeking to market a new complex financial product must meet:

(1) an "economic purpose" test, which would place the burden of proving the social and commercial utility of each proposed financial instrument on the financial institutions seeking its approval; (2) an "institutional capacity" test, which would require a review of the applicant firm's ability to effectively manage the risks and monitor the market dynamics of the proposed product; and (3) a broad "systemic effects" test, which would require a finding that approval of the proposed product would not pose an unacceptable risk of increasing systemic vulnerability

230. Press Release, Commodity Futures Trading Comm'n, CFTC Statement on Self-Certification of Bitcoin Products by CME, CFE and Cantor Exchange (Dec. 1, 2017), https://www.cftc.gov/PressRoom/PressReleases/pr7654-17.

231. Id.

232. Id.

233. 17 C.F.R. $\S 40.2$ (noting that the CFTC only needs to receive the submission "by the open of business on the business day preceding the product's listing").

234. See e.g., Hughes, supra note 195; Robert E. Litan, In Defense of Much, But Not All, Financial Innovation, BROOKINGS INST. White PAPER (Feb. 17, 2010), https://www.brookings.edu/research/in-defense-of-much-but-not-all-financial-innovation/; Suzanne Kim Ripken, Paternalism and Securities Regulation, 21 Stan. J. L. Bus. \& Fin. 1, 3 (2015); Daniel Schwarcz, Monitoring, Reporting, and Recalling Defective Financial Products, U. CHI. LEGAL F. 409 (2013).

235. Omarova, supra note 60.

236. Omarova, supra note 60 , at 67. 
and otherwise will not raise significant public policy concerns. $^{237}$

Posner and Weyl also advocate for a new product approval system that mirrors the approach the Food and Drug Administration ("FDA") takes for new pharmaceuticals. ${ }^{238}$ Posner and Weyl's proposal consists of two parts. ${ }^{239}$ First, the government would administer a test for determining whether a financial instrument is socially valuable or socially costly, with the latter being banned. ${ }^{240}$ Then, it would require an FDA-like agency for financial derivatives to review and approve all new financial products before they enter the market. ${ }^{241}$

Identifying, and advocating for, a revamped new product approval process is beyond the scope of this Article. The proposals put forth by Posner and Weyl, and Omarova, are worthy of serious consideration and an improvement over the current system. However, reforms need not be so drastic. Congress could simply eliminate the self-certification process and restore the pre-2000 product approval regime for commodity derivatives. Such a regime would require the CFTC to affirmatively approve new derivatives products and subject the agency to greater scrutiny and criticism should an approved derivative later produce widespread economic harm. Under these circumstances, the CFTC would be reticent to approve a complex new derivative that serves no economic purpose and contributes to systemic risk-like cash-settled bitcoin futures.

While it's probably too late to halt the flood of virtual currency derivatives, a new product approval regime based on pre-2000 principles could prevent future complex financial products from entering the market. For history tells us that, if left unchecked, needlessly complex products will inevitably make their way into our financial system.

237. Omarova, supra note 60.

238. Posner \& Weyl, supra note 156.

239. Posner \& Weyl, supra note 156, at 1309-1310.

240. Posner \& Weyl, supra note 156, at 1322.

241. Posner \& Weyl, supra note 156, at 1348. 